\title{
Evolution of the physico-chemical water quality in the Nam Theun 2 Reservoir and downstream rivers for the first 5 years after impoundment*
}

\section{Qualité d'eau physico-chimique dans le Réservoir de Nam Theun 2 et dans les rivières aval au cours des 5 premières années après la mise en eau}

\author{
V. Chanudet ${ }^{(1)^{\star}}$, P. Guédant ${ }^{(2)}$, W. Rode ${ }^{(2)}$, A. Godon ${ }^{(2)}$, F. Guérin ${ }^{(3,4,5)}$, \\ D. Serça ${ }^{(6)}$, C. Deshmukh ${ }^{(6)}$ and S. Descloux ${ }^{(1)}$ \\ (1) Électricité de France, Hydro Engineering Centre, Sustainable Development Dpt, Savoie Technolac, 73373 \\ Le Bourget du Lac, France \\ vincent.chanudet@edf.fr \\ (2) Nam Theun 2 Power Company Limited (NTPC), Environment \& Social Division - Water Quality \\ and Biodiversity Dept.-Gnommalath Office, PO Box 5862, Vientiane, Lao PDR \\ (3) Université de Toulouse, UPS (OMP), LMTG, 14 Av. Edouard Belin, 31400 Toulouse, France \\ (4) IRD, LMTG, 14 Av. Edouard Belin, 31400 Toulouse, France \\ (5) Departamento de Geoquimica, Universidade Federal Fluminense, Niteroi-RJ, Brasil \\ (6) Laboratoire d'Aérologie, Observatoire Midi-Pyrénées, 14 Av. Edouard Belin, 31400 Toulouse, France
}

\begin{abstract}
The physical (temperature, conductivity and turbidity) and chemical water quality $\left(\mathrm{O}_{2}, \mathrm{pH}\right.$, conductivity, nutrients, major anions and cations) characteristics have been monitored in the Nam Theun 2 system (hydroelectric reservoir and rivers downstream) for the first 5 years after impoundment. The results emphasize that the impoundment of the reservoir induced a substantial modification of the water quality in the whole aquatic system which is partially controlled by the hydrodynamics in the reservoir. During the warm seasons, the reservoir water column is thermally stratified with a warm oxic epilimnion and a colder anoxic hypolimnion. During the cold dry season or during floods, the reservoir water column over-turns which enhances oxygen penetration down to the bottom waters and contributes to a global improvement of the water quality. Downstream of the reservoir, the oxygen level was always above the minimum requirement for aquatic life due to the specific design of the water intakes at the Nakai Dam and upstream of the Power House which both favour the withdrawal of a large proportion of oxygenated epilimnic waters. Over the five years, the water quality in the reservoir itself globally improved. However, the diversion of the Nam Theun River into the Xe Bang Fai watershed via the reservoir has impacted the Xe Bang Fai River in terms of temperature, conductivity and total suspended solids.
\end{abstract}

Key words - Nam Theun 2, physico-chemical water quality, sub-tropical reservoir, hydropower, limnology

${ }^{*}$ Figures SI-1-SI-6 and Tables SI-I-SI-IV are available at the address: www.hydroecologie.org 


\begin{abstract}
Résumé - Les caractéristiques physiques (température, conductivité et turbidité) et chimiques $\left(\mathrm{O}_{2}, \mathrm{pH}\right.$, nutriments, anions et cations majeurs) de l'eau du système Nam Theun 2 (réservoir et rivières à l'aval) ont été suivies au cours des 5 premières années suivant la mise en eau. Les résultats montrent que la qualité d'eau a subi des changements substantiels dans le réservoir. Ces changements sont en grande partie contrôlés par l'hydrodynamique du réservoir. Au cours des saisons chaudes, le réservoir est stratifié thermiquement avec un épilimnion chaud et un hypolimnion plus froid et généralement anoxique. Lors de la saison froide ou suite à une crue, la colonne d'eau se mélange ce qui permet la pénétration d'oxygène jusqu'au fond de la retenue et contribue à l'amélioration globale de la qualité d'eau. À l'aval du réservoir, le niveau d'oxygénation a toujours été supérieur au minimum requis pour la vie aquatique. Ceci grâce au design spécifique des prises d'eau au barrage (débit réservé) et en amont de l'usine qui favorise l'entonnement d'une grande proportion d'eau issue de l'epilimnion. Sur les 5 années de suivi, la qualité d'eau du réservoir lui-même s'est globalement améliorée. Cependant, la dérivation de la Nam Theun dans le bassin versant de la Xe Bangfai via le réservoir a impacté cette dernière rivière en termes de température, conductivité et de matières en suspension.
\end{abstract}

Mots clés - Nam Theun 2, qualité d'eau physico-chimique, réservoir sub-tropical, hydroélectricité, limnologie

\section{INTRODUCTION}

The transformation of a riverine system into a lacustrine one induced by the creation of a reservoir modifies key hydrodynamic parameters such as water depth, current velocity, retention time, stratification or turbulences. Such changes often lead to a modification of the physico-chemical water quality. Among the main consequences observed worldwide, the build-up of dams may favour water temperature increase, depletion of oxygen associated with an increase of reduced dissolved compound $\left(\mathrm{NH}_{4}{ }^{+}\right.$, $\left.\mathrm{Fe}^{2+}, \mathrm{Mn}^{2+}, \mathrm{H}_{2} \mathrm{~S}, \mathrm{CH}_{4} \ldots\right)$ and modify the sediment balance in the rivers downstream of the dams (sediment deficit impacting habitats and geomorphology) (Baxter, 1977; Galy-Lacaux et al., 1997; Morris, 1998; Richard et al., 1997; Bergkamp et al., 2000; McCartney et al., 2001; Friedl \& Wüest, 2002; Kummu \& Varis, 2007).
The decrease of oxygen concentration occurs mainly in bottom layers, close to the water-soil/sediment interface. This degradation is the result of the decomposition of the organic matter present in the flooded soil and vegetation and in the water from the watershed (Baxter, 1977; Galy-Lacaux et al., 1999; McCartney et al., 2001; Abril et al., 2005; Guérin et al., 2008). Oxygen consumption may be also enhanced when reservoirs flood soils rich in nutrients (fertilized agricultural soil) or iron (tropical lateritic soils) for instance. These processes are all the more significant in tropical and subtropical areas where high temperatures boost chemical processes (Barros et al., 2011). In Lao People's Democratic Republic (Lao PDR), the scarce physico-chemical water quality measurements available for the Nam Ngum Reservoir a few months after impoundment (Beeton, 1991) and for the Nam Leuk Reservoir (unpublished data) 
have shown oxygen depletion at the bottom.

Another consequence of the degradation of the soil organic matter is the release of nutrients (nitrogen and phosphorus) in the water column. This sudden input of nutrients may enhance primary productivity which affects the oxygen dynamics, the whole food chain, the aquatic population dynamics as well as local use (fishing, water consumption...). Moreover, the freshly produced organic matter enhances the oxygen consumption. This trophic upsurge is commonly observed in recently flooded reservoirs in the Amazonian Basin (Vaquer et al., 1997, Agostinho et al., 1999; Gunkel et al., 2000). In Eastern Asia, many recent studies deal with physico-chemical water quality including primary production, in the newly impounded Three Gorges Reservoir (e.g. Yang et al., 2006; Yang et al., 2007; Müller et al., 2008; Tullos, 2009; Dai et al., 2010; Chen et al., 2011). Since the impoundment of Three Gorges Reservoir in 2003, substantial algae blooms have been observed, particularly during the spring dry season (Cai \& Hu, 2006; Tang et al., 2006). At this stage, it is unclear whether changes in primary production are a response to the decline in physico-chemical water quality or adaptations to the flow regime. Some authors claim that overall water quality was not degraded in certain reservoirs, partly due to the low retention time of water (Cai \& Hu, 2006). On the other hand, other studies found that the nutrient loads have been modified in the reservoir (Liu et al., 2004) and in the downstream river (Gong et al., 2006) due to enhanced soils/sediment releases. The trophic upsurge, associated with a global degradation of the physico-chemical water quality, is rapid due to the fast decomposition of the labile organic matter and the mobilization of compounds from the soils. Although oxygen demand and nutrient levels generally decrease over time as the organic matter decreases, some reservoirs require a period of more than 20 years for the development of stable water quality regimes (Baxter, 1977; Gunkel et al., 2000).

Changes of oxido-reduction conditions in recently flooded soils lead to a modification of the speciation of the compounds initially present in soils. Some species of iron, manganese or arsenic for instance can be mobilized from the soil in the water column (Young \& Ross, 2001; Peretyazhko \& Sposito, 2005; Burton et al., 2008). The release of these elements may have environmental impacts, especially in the downstream rivers. For instance many studies related to the effects of iron on the survival, mortality (Gerhardt, 1994), or the reduction of the total diversity of aquatic invertebrate communities are discussed in the literature (Beltman et al., 1999; Freund \& Petty, 2007; Lampert \& Sommer, 2008). In tropical areas, the presence of iron-rich soils (lateritic) may enhance this issue.

The assessment of the processes of physico-chemical water quality degradation - and recovery - in recently flooded reservoirs requires extensive and long-term monitoring. Examples of published pluri-annual monitoring are few, especially in tropical areas (Abril et al., 2008). During the last two decades, available studies in tropical reservoirs mainly focused on greenhouse 
gases emissions and are mostly located in the Amazonian area (Galy-Lacaux et al., 1997; Abril et al., 2005; dos Santos et al., 2005; Kemenes et al., 2007; Roland et al., 2010) or China (Chen et al., 2009). In South East Asia and especially in Lao People's Democratic Republic (Lao PDR), only little data is available for the Nam Ngum (Beeton, 1991) and Nam Leuk Reservoirs (unpublished data) or from other reservoirs in the Mekong River Basin (Bergkamp et al., 2000).

The Nam Theun 2 (NT2) Reservoir (Lao PDR) was impounded in April 2008. From this date, a comprehensive program has been implemented to monitor and model the NT2 Reservoir bio-physico-chemical water quality (Descloux et al., this issue-a). The present article focuses on physicochemistry for the first 5 years of the reservoir, supplementing studies on GHG (Deshmukh, 2013; Serça et al., this issue) and biology (bacteria, phytoplankton, zooplankton and fishes). The objectives of the paper are to i) assess the changes in physico-chemistry of the water in the Nam Theun 2 Reservoir as compared to pre-impoundment conditions (Nam Theun River) and to other tropical reservoirs with a special attention paid to iron as it appeared to be a significant issue some months after the impoundment; ii) assess the effects of the diversion of water from one watershed to another one and iii) assess the effects of the modifications of the flow regime in the Xe Bangfai River on seasonal distribution of total suspended solids.

\section{MATERIAL AND METHODS}

\subsection{The Nam Theun 2 system}

A detailed description of the system can be found in Descloux et al., (this issue-a). The NT2 Reservoir is located in Lao PDR on the Nakai Plateau (Khammouane Province) (Fig. 1). The damming of the Nam Theun River led to the formation of a $489 \mathrm{~km}^{2}$ reservoir (average depth of $8 \mathrm{~m}$ and maximum volume of 3.9 billion $\mathrm{m}^{3}$ ), at full supply level (538 $\mathrm{m}$ above sea level). The minimum environmental flow at the Dam is $2 \mathrm{~m}^{3} \cdot \mathrm{s}^{-1}$. The water coming from the Nam Theun River watershed is withdrawn in the southwest part of the reservoir (close to RES9) and released in the Xe Bangfai watershed. The mean annual inflow is $238 \mathrm{~m}^{3} . \mathrm{s}^{-1}$, distributed among tributaries in the eastern mountains. The main tributaries are the Nam Xot, Nam Theun and Nam On Rivers. Since the commissioning in March 2010, the water is withdrawn from the NT2 Reservoir through the Power House with a discharge $(Q)$ ranging from 0 to $333 \mathrm{~m}^{3} . \mathrm{s}^{-1}$. The NT2 Reservoir is characterized by large seasonal water level changes which results in a drastic reduction in the reservoir surface area at the end of the dry season.

Downstream of the Power House, water is sent to a Regulating Pond through a Tailrace Channel of $340 \mathrm{~m}$ long and a $345 \mathrm{~m}^{3} \cdot \mathrm{s}^{-1}$ capacity (Descloux et al., same issue-a). The Regulating Pond buffers the turbinated flows on a daily and weekly scale and receives natural tributaries of the Nam 


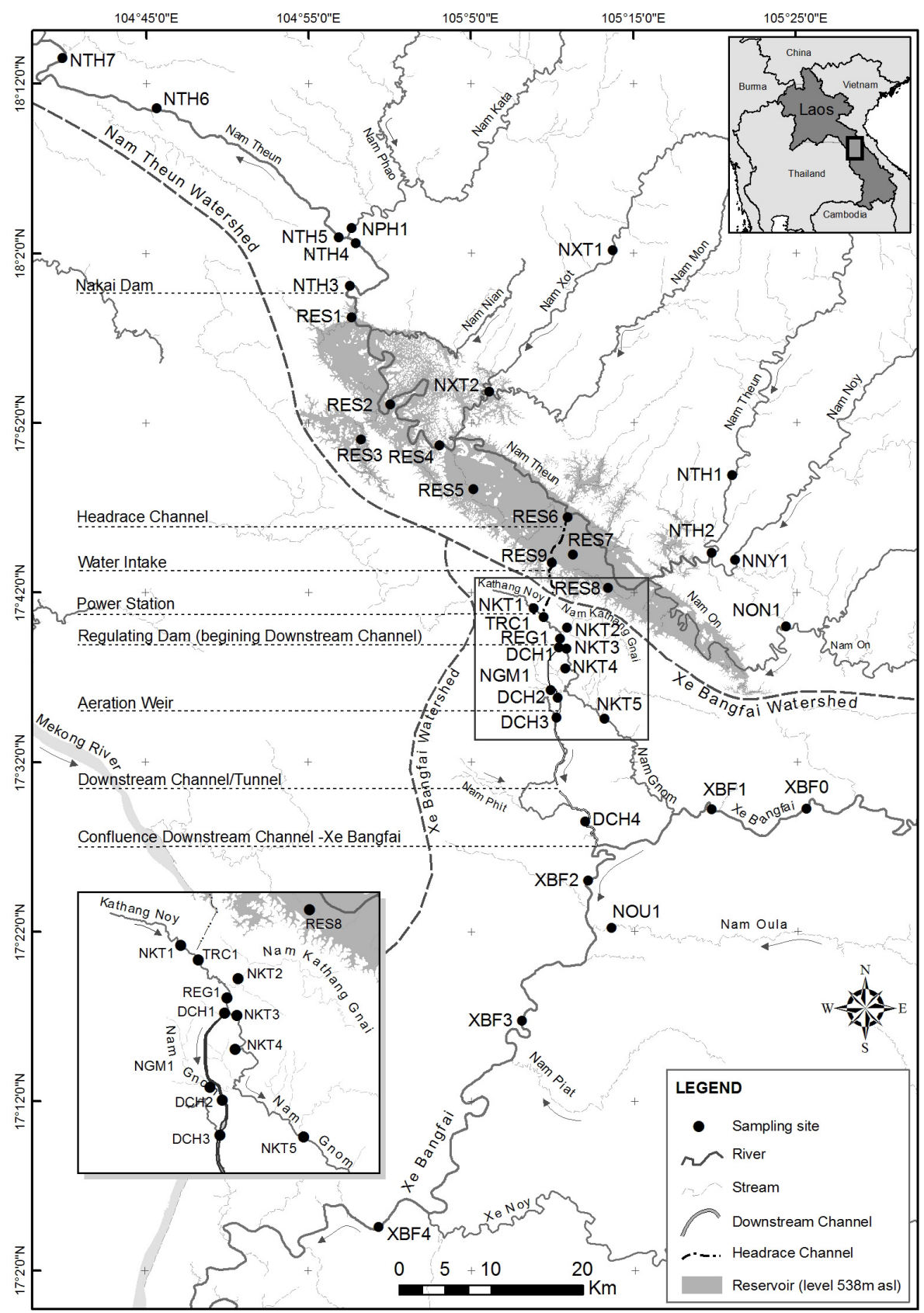

Fig. 1. Location of the NT2 site and monitoring stations (Descloux et al., same issue-a).

Fig. 1. Cartographie du site de NT2 et des stations de suivi (Descloux et al., same issue-a). 
Kathang River (Nam Kathang Noy and Gnai). Downstream of the Regulating Pond, two outflows have been constructed: (i) a riparian release to the Nam Kathang with an outflow corresponding to the natural inflow (minimum environmental flow of $0.2 \mathrm{~m}^{3} \cdot \mathrm{s}^{-1}$ ). The Nam Kathang flows into the Nam Gnom River approximately $5 \mathrm{~km}$ from the Regulating Dam, (ii) the main release through a $27 \mathrm{~km}$ long Downstream Channel towards the Xe Bangfai River (Fig. 1). The Downstream Channel is composed of rocks and soil and can evacuate a maximum flow of $330 \mathrm{~m}^{3} \cdot \mathrm{s}^{-1}$. Discharges in these systems are shown in Figure 2.

The climate is moist sub-tropical with a warm-wet (WW) season (midJune to mid-October), a cool-dry (CD) season (mid-October to mid-February) and a warm-dry (WD) season (midFebruary to mid-June).

\subsection{Monitoring data}

Physical and chemical parameters listed in Table I were measured weekly, fortnightly or monthly between April 2008 and April 2013 at each monitoring station (Descloux et al., this issue-a). The analytical methods, with the associated limits of detection and uncertainties are summarized in Table I. In the reservoir, between 3 and 6 samples were taken (peristaltic pump or sampling bottle) at each sampling point according to the thermocline and oxycline depths. In the rivers, only surface water was collected (grab sampling). Sampling was usually done between 10 a.m. and 2 p.m. local time (UTC time).

\subsection{Data treatment}

All differences between values have been statistically tested with one way analysis of variance (ANOVA) with the software SigmaPlot ${ }^{\circledR}$. The HolmSidak test has been used for pairwise comparisons. The overall significance level is 0.05 .

Fluxes were estimated with the program FLUX (1999) from concentration data and continuous flow records. According to the quality of the relationship between log(concentration) and log(flow), the user selects the most appropriate calculation method (Walker, 1999). When the correlation is good, a method whereby the concentration/flow regression equation is applied individually to each daily flow is used. Otherwise, load is estimated by multiplying the flow weighted average concentration by the mean flow over the relevant period. A more detailed description of the procedure is available in Chanudet \& Filella (2007).

In the box plots, the continuous line indicates the median and the dotted line the average. The bottom and top of the box are the 25th and the 75th percentiles while whiskers indicate the 10th and 90th percentiles.

\section{RESULTS}

\subsection{Tributaries of the Nam Theun 2 Reservoir}

The temperature was the same for the three rivers during the WD $\left[20.3^{\circ} \mathrm{C}-32.0^{\circ} \mathrm{C}\right]$ and WW $\left[20.8^{\circ} \mathrm{C}-\right.$ 


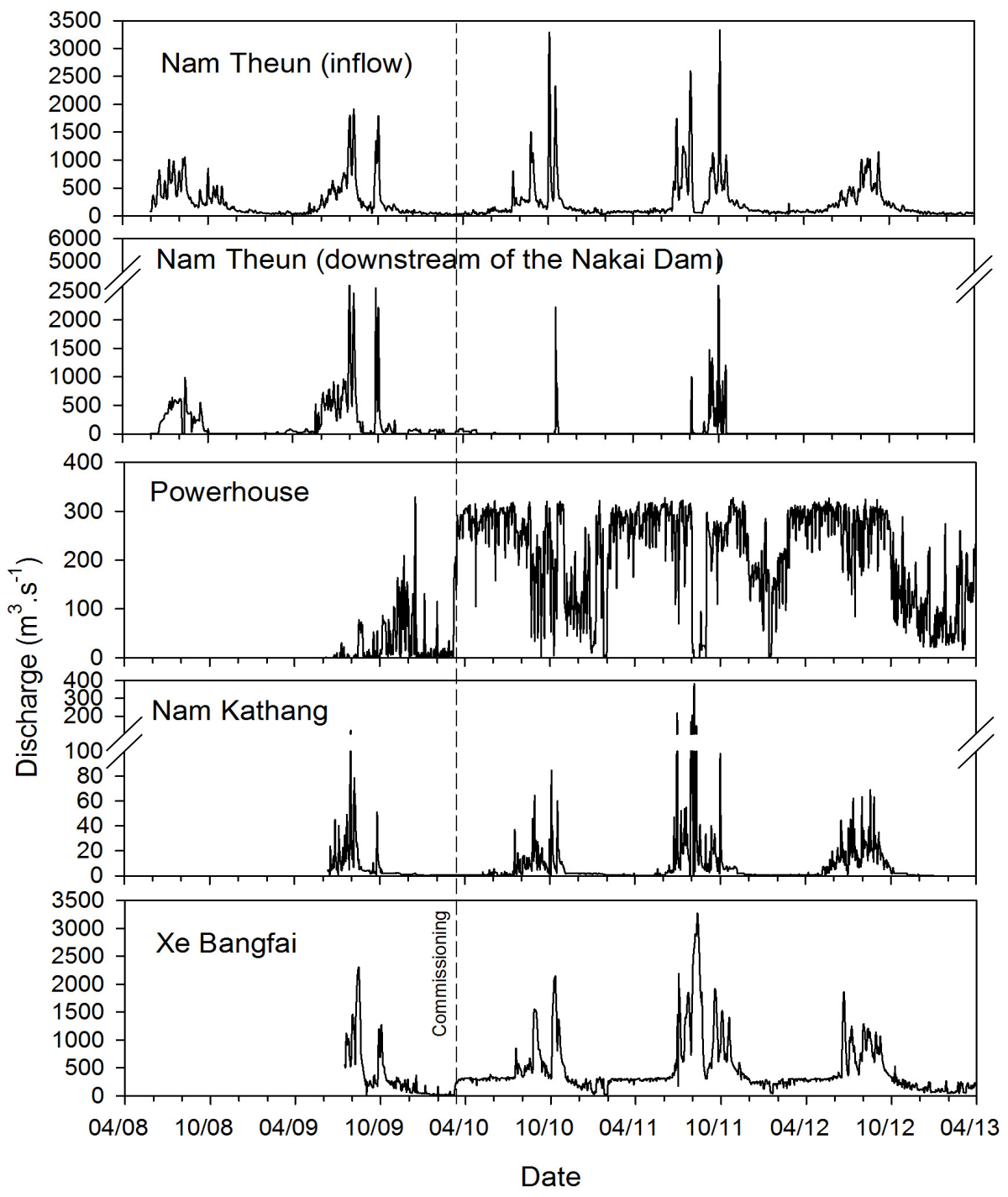

Fig. 2. Average daily discharge $\left(\mathrm{m}^{3} . \mathrm{s}^{-1}\right)$ in the Nam Theun River downstream of the Reservoir, in the Downstream Channel, downstream of the Power House, in the Nam Kathang River through the Regulating Pond releases and in the Xe Bangfai River at Mahaxai, downstream of the confluence with the Downstream Channel (Descloux et al., same issue-a).

Fig. 2. Débits moyens journaliers $\left(\mathrm{m}^{3} \cdot \mathrm{s}^{-1}\right)$ dans la rivière Nam Theun en aval du Réservoir, dans le Downstream Channel en aval des turbines, dans la Nam Kathang en aval du Regulating Pond, et dans la Xe Bangfai à Mahaxai en aval de la confluence avec le Downstream Channel (Descloux et al., same issue-a). 


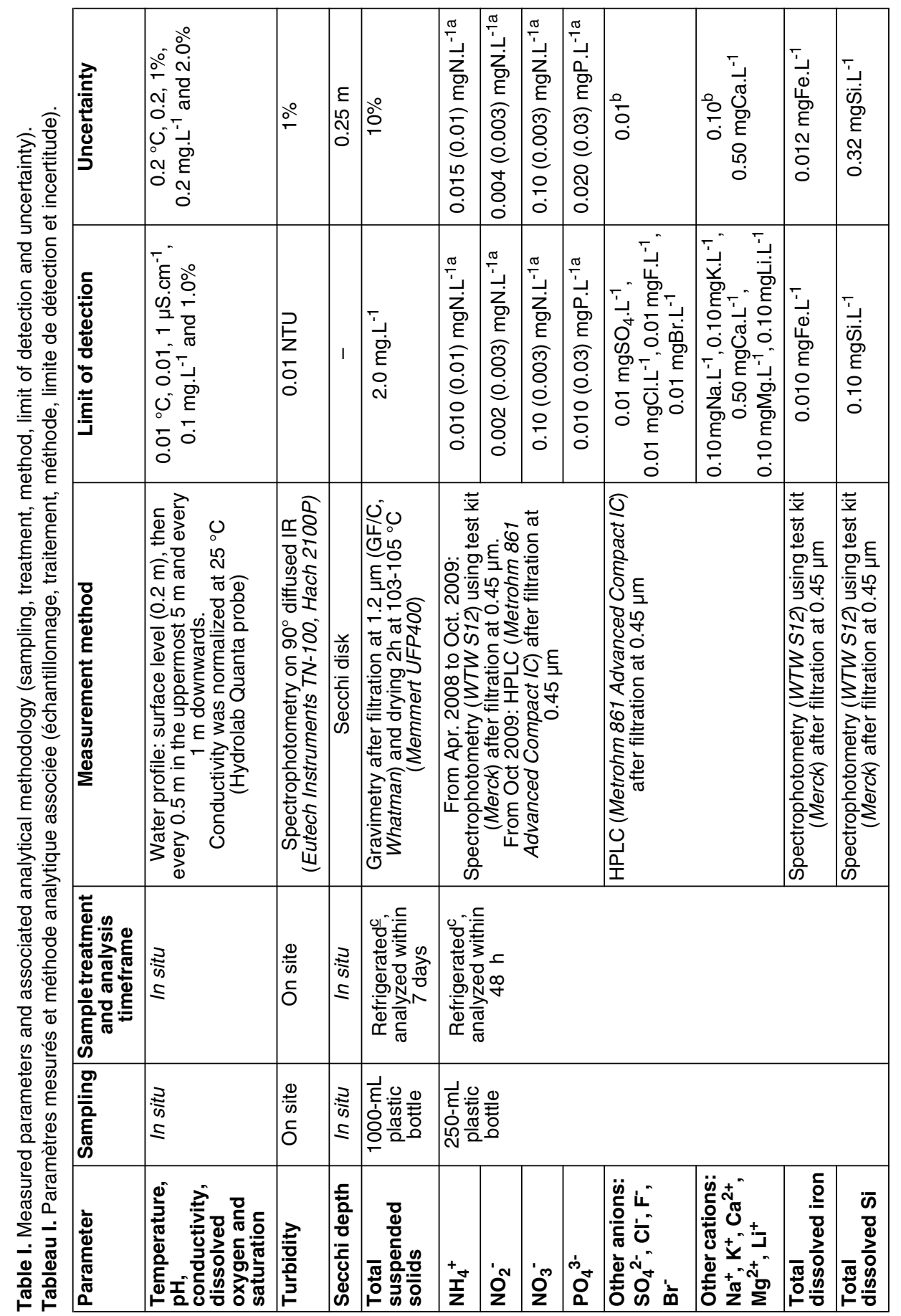




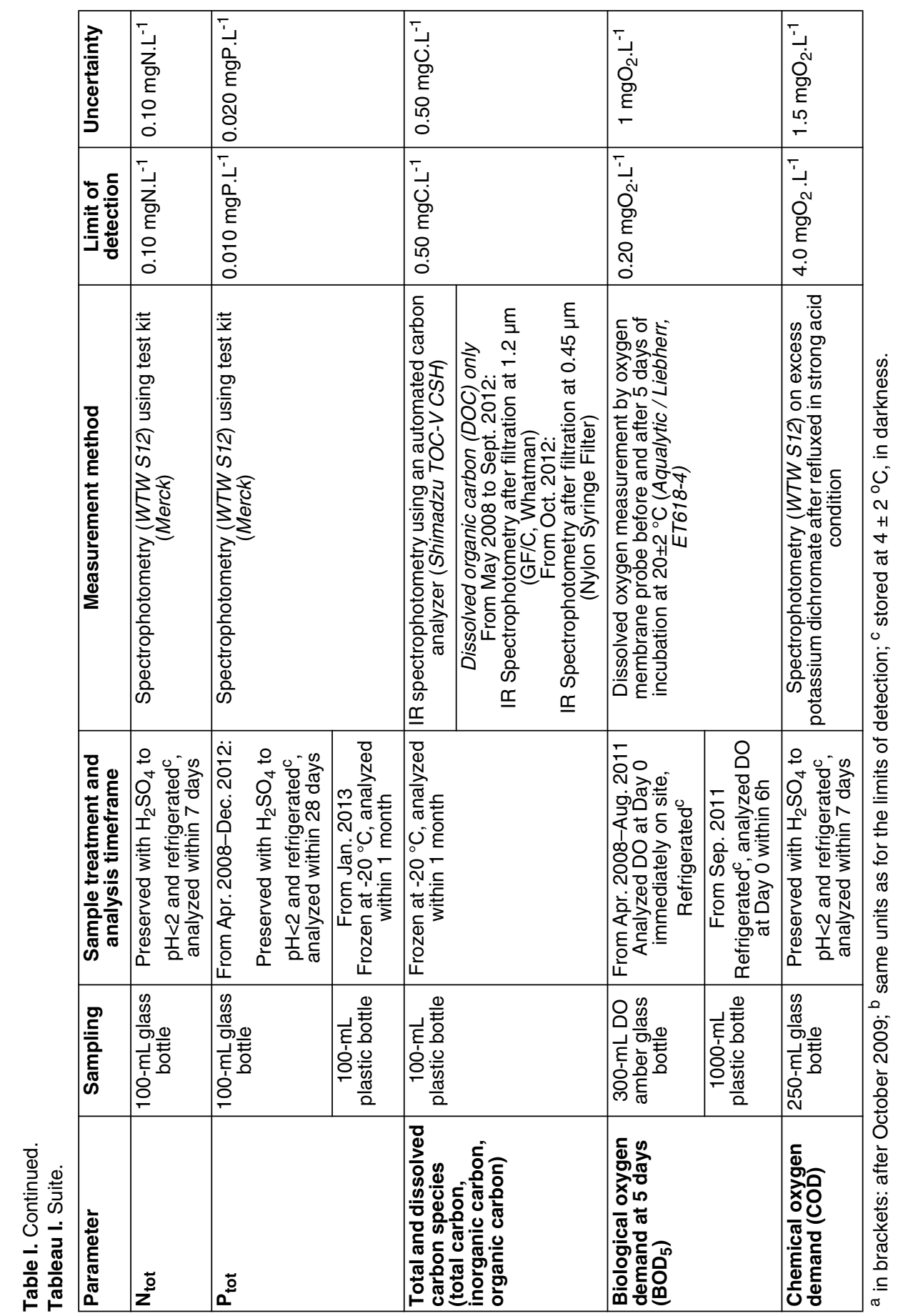


$30.5^{\circ} \mathrm{C}$ ] seasons. It decreased significantly in the three rivers during the $\mathrm{CD}$ season, ranging from 17.6 to $28.8^{\circ} \mathrm{C}$, but did not differ between the rivers (Fig. SI-1). Dissolved oxygen was also similar between the rivers and the seasons $\left[4.40-10.36 \mathrm{mgO}_{2} \cdot \mathrm{L}^{-1}, 55-124 \%\right.$ of saturation], except in the Nam On River where a lower concentration was measured during the $C D$ season [1.49-8.97 $\left.\mathrm{mgO}_{2} \cdot \mathrm{L}^{-1}, 17-105 \%\right]$. The $\mathrm{pH}$ in the Nam Xot and Nam Theun Rivers were similar throughout the year [5.66-8.60] whereas it was lower in the Nam On River during the WW [5.017.76] and CD [4.97-7.79] seasons (Fig. SI-1). Conductivity was higher in the Nam Theun River [20-65 $\mu \mathrm{S} . \mathrm{cm}^{-1}$ ] than in the other rivers whatever the seasons [10-42 $\left.\mu \mathrm{S} . \mathrm{cm}^{-1}\right]$. In all rivers, the conductivity was lower during the WW season $\left(21.6 \mu \mathrm{S} . \mathrm{cm}^{-1}\right.$ in average, $\left.\left[10-52 \mu S . \mathrm{cm}^{-1}\right]\right)$ than during the WD season $\left(33.0 \mu \mathrm{S} . \mathrm{cm}^{-1}\right.$ in average, [12$\left.\left.65 \mu \mathrm{S} . \mathrm{cm}^{-1}\right]\right)$. Major anions and cations showed the same evolution as conductivity (Tabs. SI-I and SI-II). $\mathrm{SO}_{4}{ }^{2-}, \mathrm{Cl}^{-}$, $\mathrm{Na}^{+}, \mathrm{K}^{+}, \mathrm{Ca}^{2+}$ and $\mathrm{Mg}^{2+}$ concentrations are higher in the Nam Theun River than in other rivers only during the WD season.

There was no statistical seasonal or spatial variation of nitrate and ammonium concentrations (Fig. SI-1). Nitrate concentrations ranged between $<0.002$ and $0.44 \mathrm{mgN} . \mathrm{L}^{-1}$ with an average value of $0.10 \mathrm{mgN} \cdot \mathrm{L}^{-1}$. Average ammonium concentrations were 0.01 , 0.05 and $0.05 \mathrm{mgN}^{-\mathrm{L}^{-1}}$ for the Nam Xot, Nam Theun and Nam On Rivers, respectively. These concentrations of $\mathrm{N}$ species were close to that estimated by Lewis (2008) for tropical streams for a runoff of $1900 \mathrm{~mm} . \mathrm{yr}^{-1}$. Phosphorus concentrations were on average $0.04 \mathrm{mgP} . \mathrm{L}^{-1}$ in all rivers and fluctuated by one order of magnitude (between $<0.02$ and $0.27 \mathrm{mgP} . \mathrm{L}^{-1}$ ). No clear conclusion can be drawn on this parameter since no significant difference was observed between seasons and rivers. Almost all phosphate measurements were below the limit of detection (10 and $30 \mu \mathrm{gP} . \mathrm{L}^{-1}$ after October 2009). The average TSS concentration was $3.8 \mathrm{mg} \cdot \mathrm{L}^{-1}$ with values ranging from 0.2 and $16.4 \mathrm{mg} \cdot \mathrm{L}^{-1}$. No significant differences were observed among stations and seasons. The variability of concentrations was higher during WD and WW seasons. During the CD season, a significant increase of TSS concentrations was observed in the Nam On River only. Dissolved organic carbon concentrations were higher in the Nam On River [1.18-5.53 mg. $\mathrm{L}^{-1}$ ] than in the other rivers for all seasons $[<0.5$ to $\left.3.01 \mathrm{mg} \cdot \mathrm{L}^{-1}\right]$. The average biochemical oxygen demand was $1.40 \pm 1.21$, $1.45 \pm 0.97$ and $1.70 \pm 1.65 \mathrm{mgO}_{2} \cdot \mathrm{L}^{-1}$ for the Nam Xot, Nam Theun and Nam On Rivers, respectively. No statistical difference on total dissolved iron concentrations was measured among the three rivers. The average value was $0.32 \mathrm{mgFe} . \mathrm{L}^{-1}$ with values ranging from 0.005 to $1.77 \mathrm{mgFe} . \mathrm{L}^{-1}$.

\subsection{The Nam Theun 2 Reservoir}

From March (WD season), a warm water layer appeared at the surface with a firmly established thermocline at a depth of approximately $5-10 \mathrm{~m}$ by the end of June (Figs. 3 and SI-2). The average surface and bottom temperatures at RES1 were $26.8^{\circ} \mathrm{C}\left[18.2-30.6^{\circ} \mathrm{C}\right]$ 


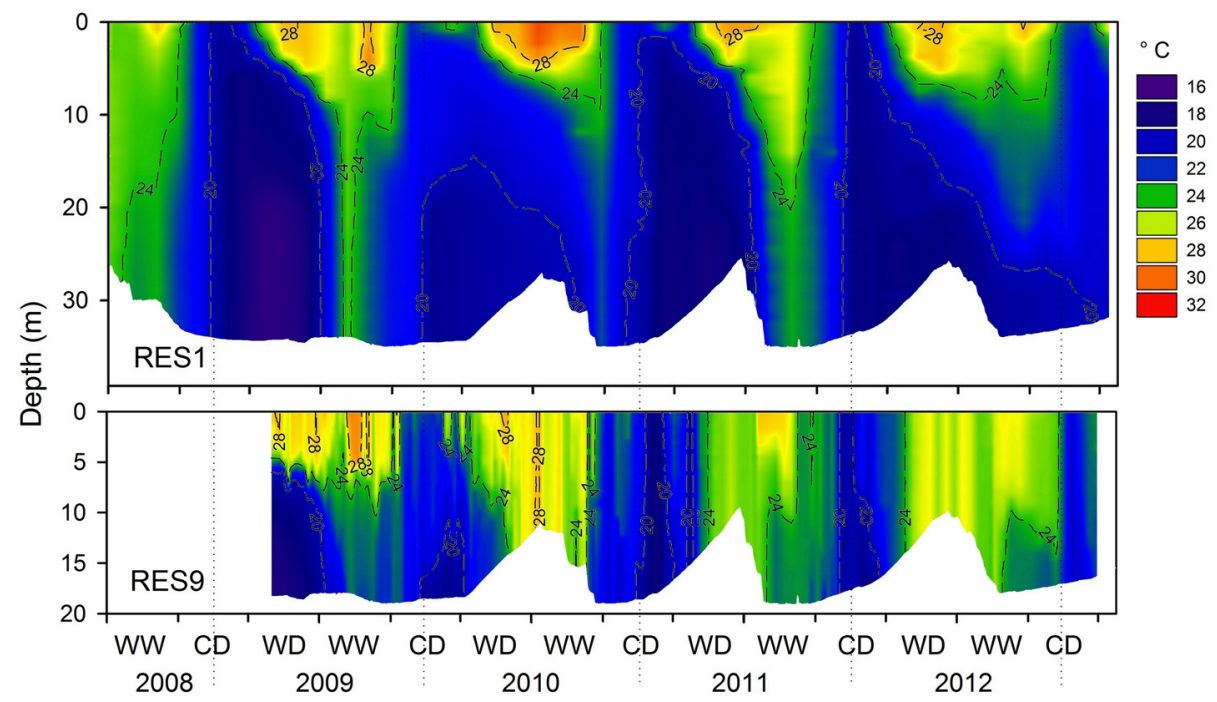

Fig. 3. Water temperature $\left({ }^{\circ} \mathrm{C}\right)$ profiles in the Nam Theun 2 Reservoir (RES1 and RES9) between 2008 and 2013 (WD: warm dry season, WW: warm wet season, CD: cool dry season).

Fig. 3. Profils de température de l'eau $\left({ }^{\circ} \mathrm{C}\right)$ dans le Réservoir de Nam Theun 2 (RES1 et RES9) entre 2008 et 2013 (WD : saison chaude et sèche, WW : saison chaude et humide, CD : saison fraîche et sèche).

and $18.9^{\circ} \mathrm{C}\left[16.7-27.2^{\circ} \mathrm{C}\right]$, respectively. From June-July to November (WW season), complete or partial destratification events occurred irregularly due to the rapid increase in tributary discharges and current velocities in the reservoir. The average surface and bottom temperatures at RES1 were then $27.1^{\circ} \mathrm{C}$ [22.9-31.2 ${ }^{\circ} \mathrm{C}$ ] and $21.4^{\circ} \mathrm{C}$ [18.5-25.6 $\left.{ }^{\circ} \mathrm{C}\right]$. Finally, during the $\mathrm{CD}$ season, the whole water column experienced a temperature decrease and a homogenisation in the water column $\left(22.0^{\circ} \mathrm{C}\left[18.5-28.5^{\circ} \mathrm{C}\right]\right.$ and $19.7^{\circ} \mathrm{C}$ [17.5-22.1 ${ }^{\circ} \mathrm{C}$ ] for surface and bottom temperatures, respectively, at RES1. The seasonal patterns were the same for all the reservoir stations except RES9. For this one, and from the commissioning in March 2010, the vertical gradient was almost absent as compared to the other stations. The differences between surface and bottom water temperature at RES9 (from March 2010) were $0.8,1.4$ and $1.5^{\circ} \mathrm{C}$ for the WD, WW and CD seasons, respectively. In another station with the same depth (RES8), these differences were $7.7,3.8$ and $2.1^{\circ} \mathrm{C}$. At the annual scale, the reservoir overturn occurred generally in December, except during the 2012-2013 CD season when it happened in January 2013. Secchi depth increased significantly between 2008 and 2009 and then stabilized at around $2.09 \pm 0.15 \mathrm{~m}$.

During the WD season, the development of the thermocline coincided with the development of an oxic layer in the uppermost meters. During the WW 


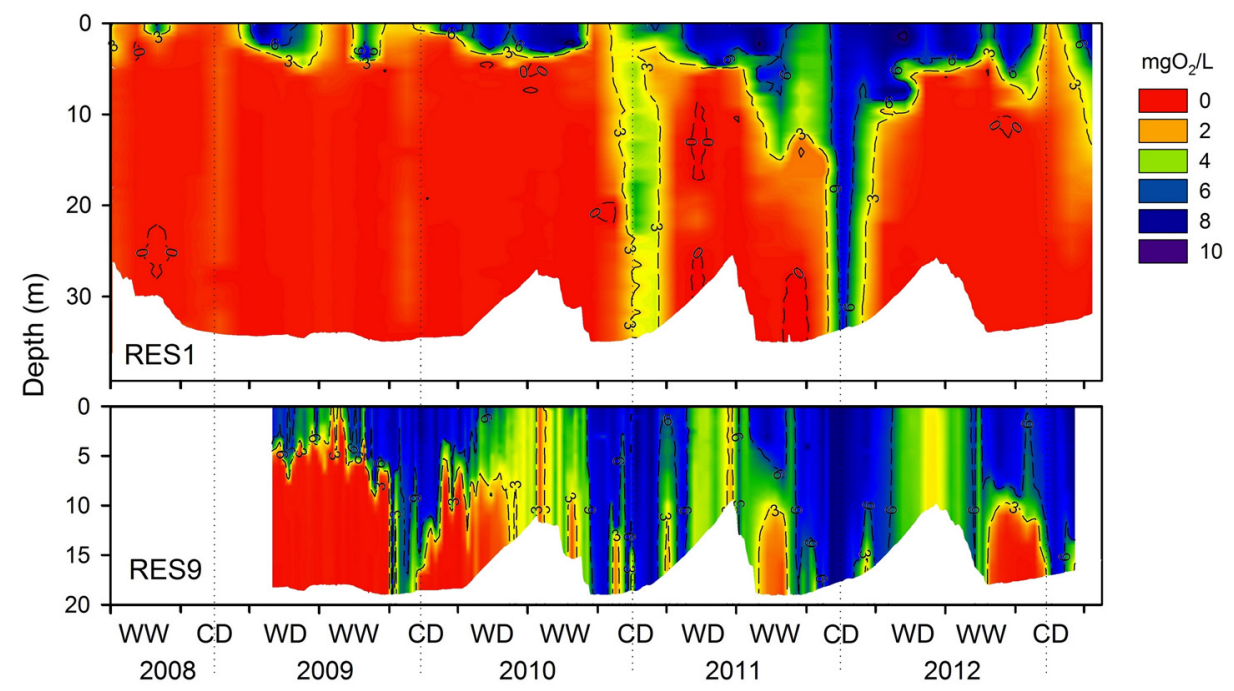

Fig. 4. Dissolved oxygen (mg. $\mathrm{L}^{-1}$ ) profiles in the Nam Theun 2 Reservoir (RES1 and RES9) between 2008 and 2013 (WD: warm dry season, WW: warm wet season, CD: cool dry season).

Fig. 4. Profils d'oxygène dissous (mg. $\mathrm{L}^{-1}$ ) dans le Réservoir de Nam Theun 2 (RES1 et RES9) entre 2008 et 2013 (WD : saison chaude et sèche, WW : saison chaude et humide, CD : saison fraîche et sèche).

season, the oxygen stratification can be lowered with a partial homogenisation of the water column. Finally, when the reservoir overturned (CD season), dissolved oxygen was distributed homogeneously in the whole water column (Figs. 4 and SI-3). Significant geographical and inter-annual differences can be observed for dissolved oxygen. At RES1, the thickness of the oxic layer during the different stratification periods increased from about $0 \mathrm{~m}$ in 2008 to $5 \mathrm{~m}$ in 2013. In 2011, the combination of a very rainy WW season and an efficient destratification during the $C D$ season induced a significant increase of the oxygenation at the end of the year (Fig. 4). On the contrary, an anoxia was observed at the end of 2012 in almost the whole water column for some days. In the isolated area of the Nam Malou River (RES3), the thickness of the oxic layer had the same evolution as at RES1 (Fig. SI-3). However, the impact of annual destratification was not clearly observed at the frequency of our observations. In the South East zone of the reservoir (RES8), oxygen concentration was higher than in RES1 (Fig. SI-3). During the 2008-2009 CD season (8 months after impoundment), the whole water column was already oxic. Between 2009 and 2013, we observed an increase in duration and frequency of periods during which the whole water column (up to $20 \mathrm{~m}$ ) was oxic. Between June 2008 to June 2009 and between June 2011 and 2012, the oxygen concentration was above $1 \mathrm{mg} \cdot \mathrm{L}^{-1}$ for 


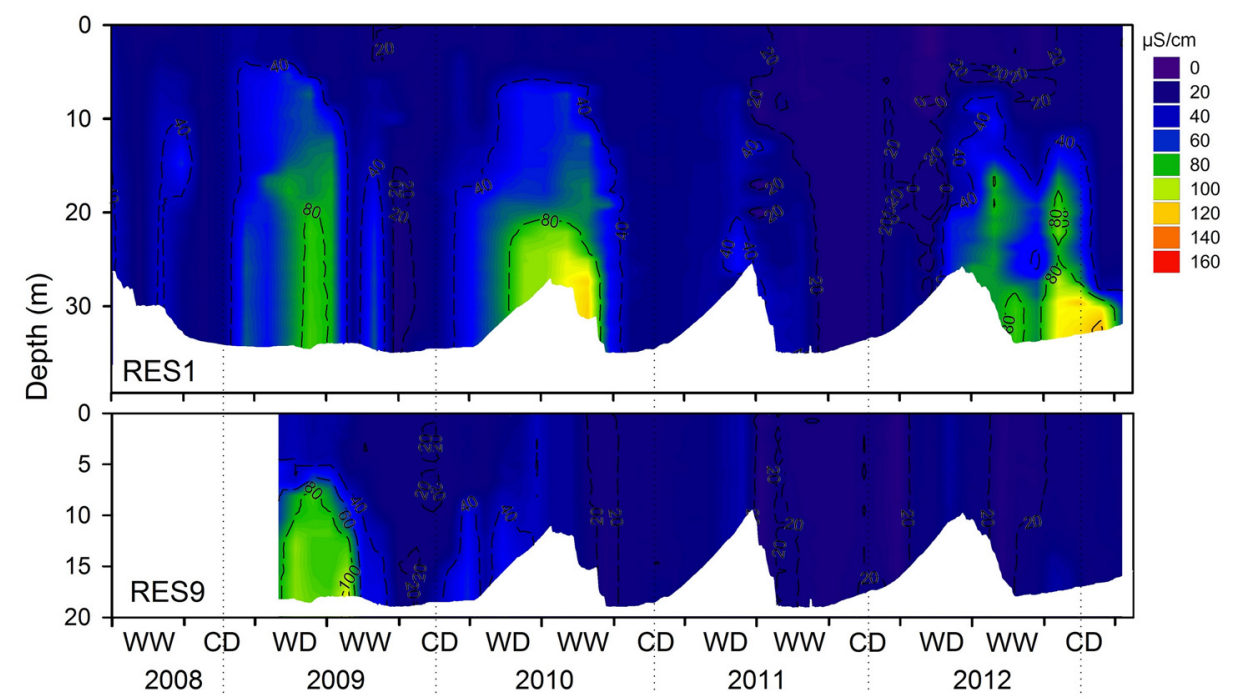

Fig. 5. Conductivity $\left(\mu \mathrm{S} . \mathrm{cm}^{-1}\right)$ profiles in the Nam Theun 2 Reservoir (RES1 and RES9) between 2008 and 2013 (WD: warm dry season, WW: warm wet season, CD: cool dry season).

Fig. 5. Profils de conductivité de l'eau $\left(\mu \mathrm{S} . \mathrm{cm}^{-1}\right)$ dans le Réservoir de Nam Theun 2 (RES1 et RES9) entre 2008 et 2013 (WD : saison chaude et sèche, WW : saison chaude et humide, CD : saison fral̂che et sèche).

48 days and 211 days, respectively. Close to the water intake (RES9), the whole water column was almost always oxygenated, starting from March 2010 (Fig. 4). Before this date, oxygen concentration was similar to that at RES8.

The evolution of $\mathrm{pH}$ values with time and depth is not as clear as for temperature and oxygen (Fig. Sl-4). In the hypolimnion, values were lower (below 6.5) than in the incoming rivers. In the epilimnion, values tended to increase since the impoundment, especially during the WD season (up to 8.5).

Average conductivity in surface water was $23.9 \mu \mathrm{S} . \mathrm{cm}^{-1}$ with a maximum value of $65 \mu \mathrm{S} . \mathrm{cm}^{-1}$ at RES1 (Fig. 5). These values were close to those measured in the tributaries. In the hypolimnion, conductivity (i) increased during the WD seasons (stratified conditions and anoxia) and (ii) decreased during WW and CD seasons when the reservoir overturned. Lower conductivity values were measured at RES9 (and RES8) where oxygen concentrations were high (Figs. 5 and SI-5). Except at RES9, the highest bottom values were not measured immediately after the impoundment but in 2010 and 2012. The delayed destratification for the 2012-2013 CD season was also obvious with an unusual increase of conductivity at the bottom at the end of 2012 (RES1).

Conductivity is a good proxy for reduced compound concentrations since there were good correlations between conductivity and $\mathrm{NH}_{4}{ }^{+}\left(\mathrm{r}^{2}=0.76\right)$ and 


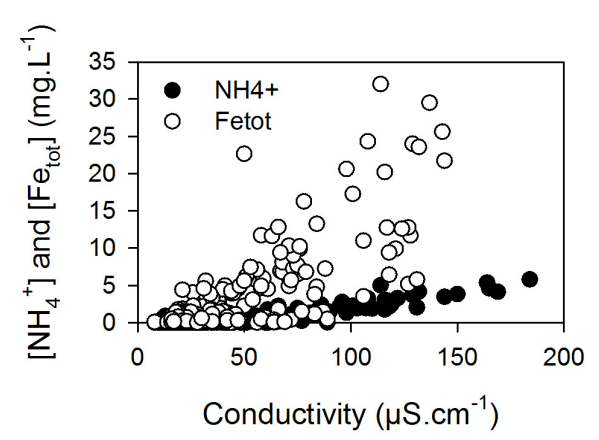

Fig. 6. Relationship between conductivity and $\mathrm{NH}_{4}{ }^{+}$and total dissolved iron in the reservoir.

Fig. 6. Relation entre la conductivité et $\mathrm{NH}_{4}{ }^{+}$et le fer total dissous dans le réservoir.

total dissolved iron $\left(r^{2}=0.66\right)($ Fig. 6) while conductivity and calcium were not correlated $\left(r^{2}=0.04\right)$. The seasonal and inter-annual evolutions were the same. The highest $\mathrm{NH}_{4}{ }^{+}$concentrations were measured at the bottom in 2010 and 2012-2013 (up to 5.4 mgN.L $^{-1}$, average: $0.60 \pm 0.81 \mathrm{mgN}^{-1} \mathrm{~L}^{-1}$ ) (Figs. 7 and 8 ). There was no initial peak following the impoundment. When the reservoir overturned, $\mathrm{NH}_{4}{ }^{+}$concentration increased in surface water, up to $0.8 \mathrm{mgN}^{-\mathrm{L}^{-1}}$ (average during CD season: $0.07 \pm 0.09 \mathrm{mgN} \cdot \mathrm{L}^{-1}$ and annual average: $\left.0.05 \pm 0.11 \mathrm{mgN} . \mathrm{L}^{-1}\right)$. The highest surface values measured during or immediately after concentration peaks have been measured in the hypolimnion. Contrary to $\mathrm{NH}_{4}{ }^{+}, \mathrm{NO}_{3}{ }^{-}$ surface and bottom concentrations were of the same order of magnitude $\left(0.04 \pm 0.08 \mathrm{mgN} . \mathrm{L}^{-1}\right.$ in surface and $0.06 \pm 0.09 \mathrm{mgN}^{-\mathrm{L}^{-1}}$ at the bottom) and within the range of the tributaries. Close to the Nakai Dam (RES1), highest surface and bottom $\mathrm{NO}_{3}{ }^{-}$values were measured immediately after the impoundment. After an initial peak following the impoundment, $\mathrm{NO}_{2}^{-}$concentrations decreased with time, both at the surface and the bottom of the reservoir (Figs. 7 and 8).

Total phosphorus concentrations did not exhibit a clear evolution with time. No initial peak has been observed and both surface and bottom values are low throughout the years $(0.04 \pm$ 0.08 and $0.05 \pm 0.09 \mathrm{mgP}^{-\mathrm{L}^{-1}}$ in average for surface and bottom, respectively). Phosphate concentrations were almost always below the limit of detection.

A limited increase in chlorophyll a concentration at RES1 (surface) can be observed during the first two years (Fig. 7). However, values were usually below $10 \mu \mathrm{g} \cdot \mathrm{L}^{-1}$. At the whole Reservoir scale, the annual mean were 12.5, 8.7 and $4.3 \mu \mathrm{g} . \mathrm{L}^{-1}$ for 2010, 2011 and 2012, respectively (Martinet et al., same issue). After a high production period of one year following the impoundment, the NT2 Reservoir tends toward stable oligo-mesotrophic status (Martinet et al., same issue).

Dissolved organic carbon was higher in surface water (average: $2.66 \pm$ $1.27 \mathrm{mgC}^{-1} \mathrm{~L}^{-1},\left[0.5-7.63 \mathrm{mgC} . \mathrm{L}^{-1}\right]$ and also during the WD and WW seasons. At the bottom, values were lower and less variable than at the surface (average: $1.82 \pm 0.86 \mathrm{mgC.} \mathrm{L}^{-1},[0.5-$ $\left.\left.5.66 \mathrm{mgC}^{-1} \mathrm{~L}^{-1}\right]\right)$.

The seasonal dynamics of total dissolved iron was very close to that of $\mathrm{NH}_{4}{ }^{+}$(Fig. 6). Highest values were measured at the bottom not immediately after the impoundment but during the stratified seasons in 2009 (5.70 mg. $\mathrm{L}^{-1}$ and $8.09 \mathrm{mg} . \mathrm{L}^{-1}$ in average at RES1 and for all reservoir stations, respectively) and 2010 (7.81 mg. $\mathrm{L}^{-1}$ and $\left.11.5 \mathrm{mg} . \mathrm{L}^{-1}\right)$ 


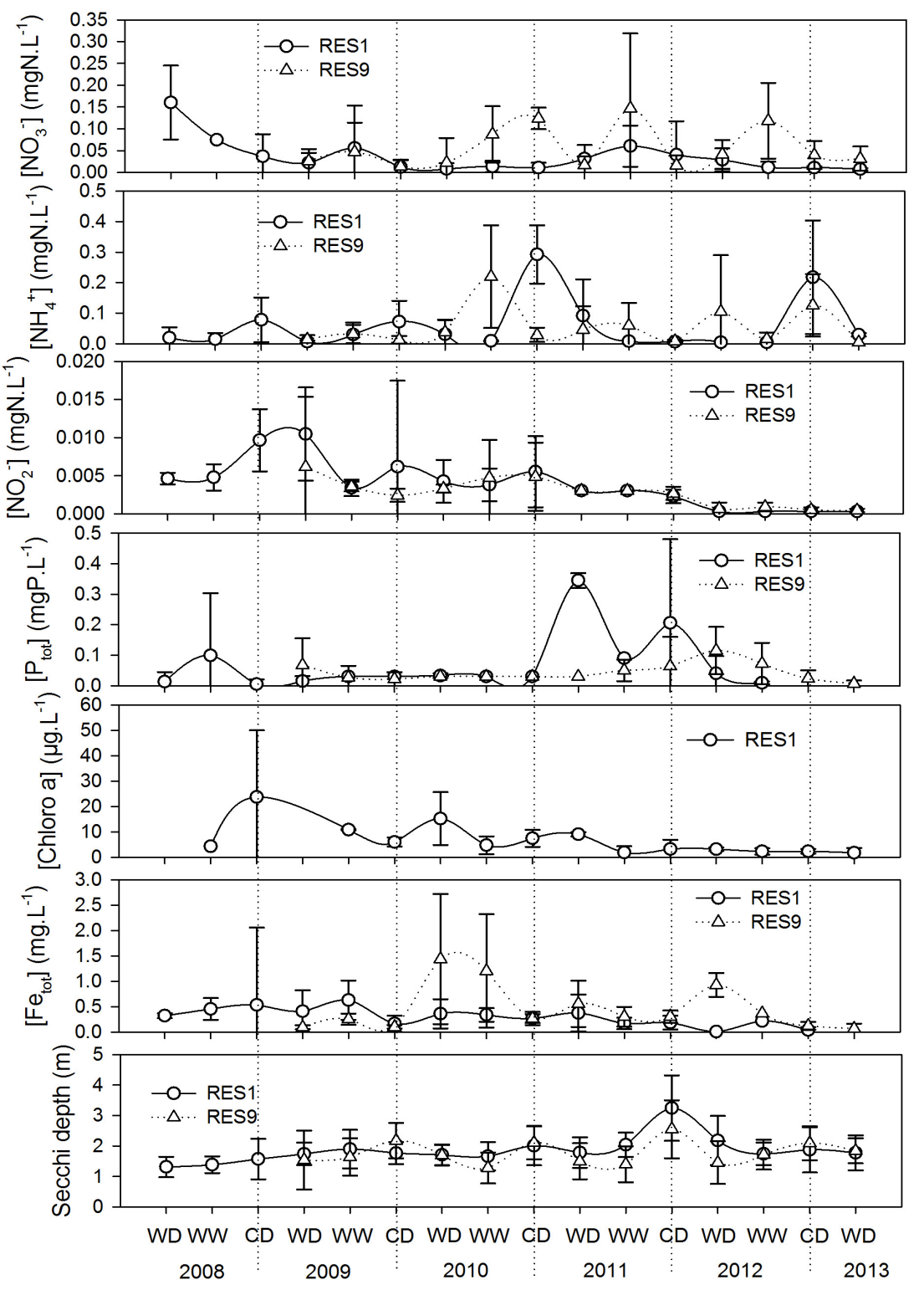

Fig. 7. Surface seasonal physico-chemical water quality in the Nam Theun 2 Reservoir, continuous lines: RES1, broken lines: RES9) between 2008 and 2013 (WW: warm-wet season).

Fig. 7. Qualité d'eau physico-chimique saisonnière en surface du Réservoir de Nam Theun 2, lignes continues : RES1, lignes pointillées : RES9) entre 2008 et 2013 (WW : saison chaude et humide). 


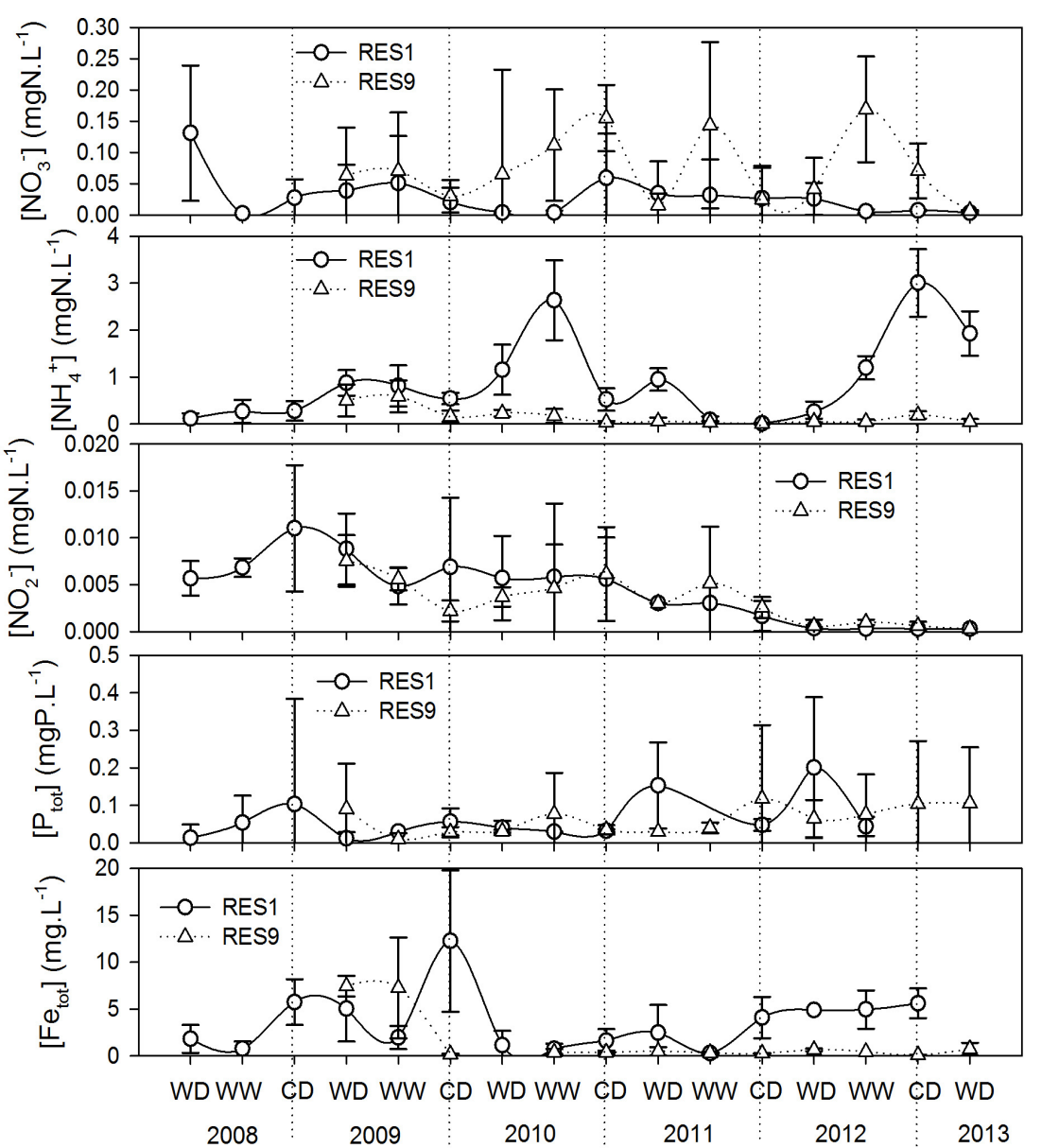

Fig. 8. Bottom seasonal physico-chemical water quality in the Nam Theun 2 Reservoir, continuous lines: RES1, broken lines: RES9) between 2008 and 2013 (WW: warm-wet season).

Fig. 8. Qualité d'eau physico-chimique saisonnière au fond du Réservoir de Nam Theun 2, lignes continues : RES1, lignes pointillées : RES9) entre 2008 et 2013 (WW : saison chaude et humide).

while observing the highest conductivity values. At RES7, iron bottom concentration reached $37.9 \mathrm{mg} . \mathrm{L}^{-1}$ in September 2010 (maximum value). However, unlike $\mathrm{NH}_{4}^{+}$during the 2012-2013 CD season, total dissolved iron concentration $\left(4.95 \mathrm{mg} . \mathrm{L}^{-1}\right.$ at
RES1) at the bottom did not reach its highest value again such as that measured in 2010. On average since the impoundment, the average bottom and surface concentrations in the reservoir were $5.29 \mathrm{mg} \cdot \mathrm{L}^{-1}$ and $0.38 \mathrm{mg} \cdot \mathrm{L}^{-1}$, respectively. 


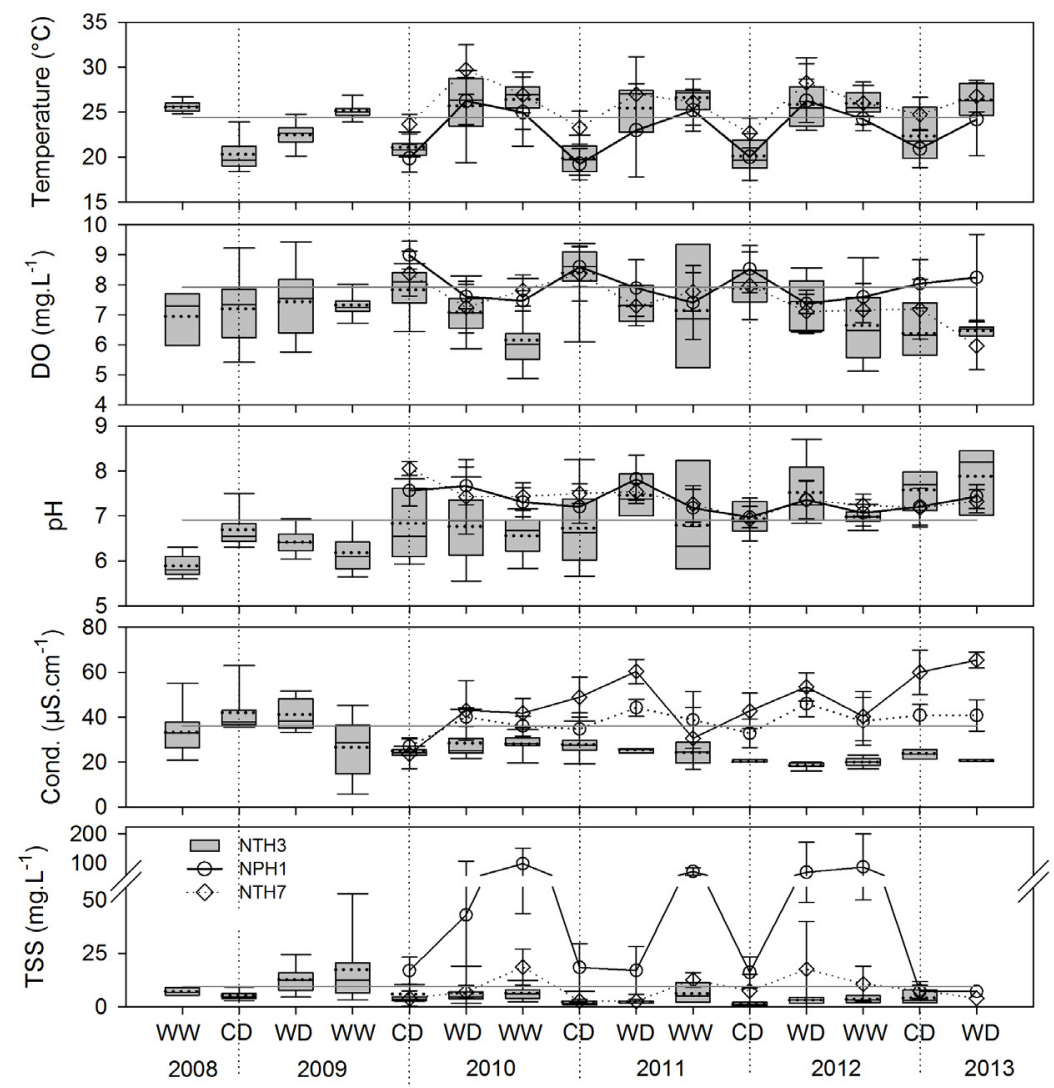

Fig. 9. Seasonal (warm-dry (WD), warm-wet (WW) and cool-dry (CD) seasons) physico-chemical water quality in the Nam Theun (NTH3: box plots; NTH4: continuous lines; NTH7: broken lines) and Nam Phao (NPH1: dotted lines) Rivers downstream the Nakai Dam. The dark grey lines indicate the average values measured between 2005 and March 2008 at NTH3.

Fig. 9. Qualité d'eau physico-chimique saisonnière dans les rivières Nam Theun (boîte à moustaches : NTH3, lignes continues : NTH4, lignes discontinues : NTH7) et Nam Phao (lignes pointillées : $\mathrm{NPH} 1$ ) à l'aval du barrage de Nakai. Les lignes en gris indiquent les valeurs moyennes mesurées entre 2005 et mars 2008 à NTH3.

\subsection{Nam Theun River downstream Nakai Dam}

The same seasonal features can be observed between the reservoir (Figs. 3 to 5) and the downstream Nam Theun River (Figs. 9 and 10). For water temperature, no significant difference can be observed between NTH3 and (i) the non-impacted Nam Phao River (NPH1) and (ii) the furthest station on the Nam Theun River (NTH7). Results from an automatic measurement station located downstream the confluence with the Nam Phao River indicated daily variations of about $2{ }^{\circ} \mathrm{C}$. Oxygen concentration in the released water was always above $4 \mathrm{mgO}_{2} \cdot \mathrm{L}^{-1}$ or 


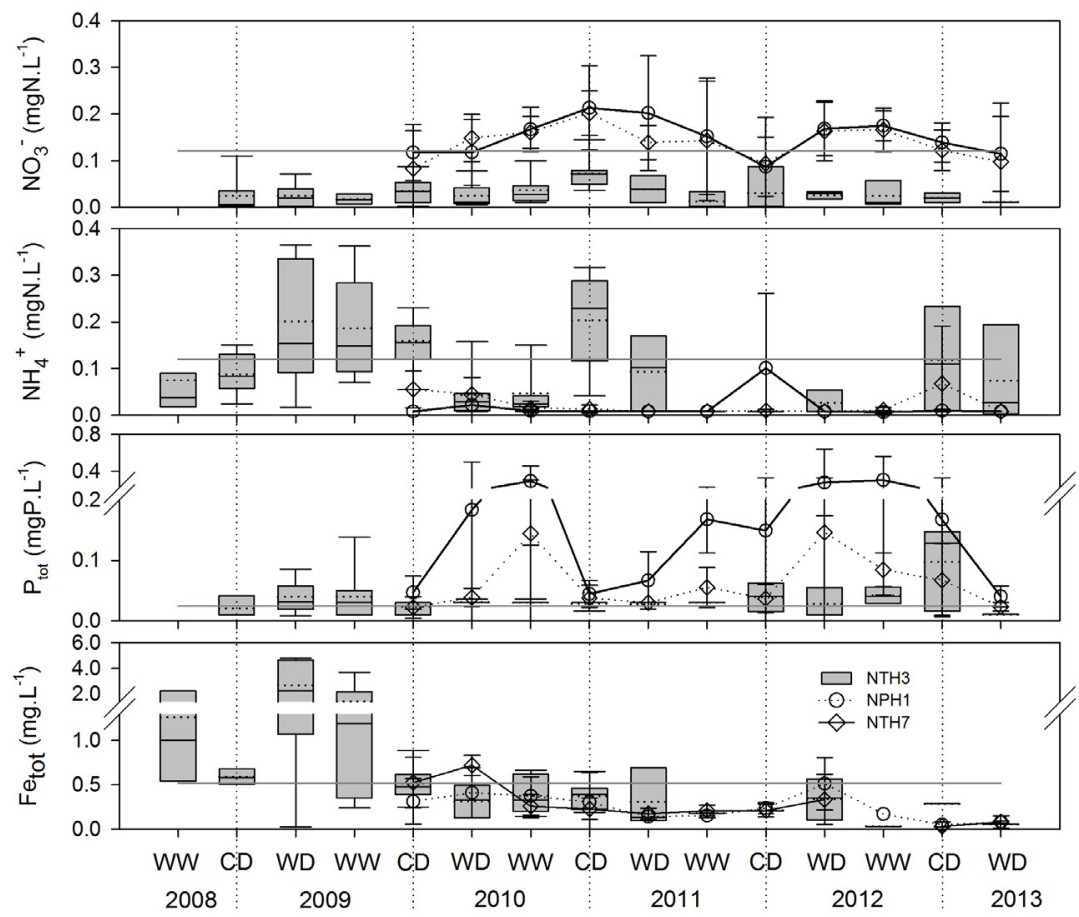

Fig. 10. Seasonal (warm-dry (WD), warm-wet (WW) and cool-dry (CD) seasons) physico-chemical water quality in the Nam Theun (NTH3: box plots; NTH4: continuous lines; NTH7: broken lines) and Nam Phao (NPH1: dotted lines) Rivers downstream the Nakai Dam. The dark grey lines indicate the average values measured between 2005 and March 2008 at NTH3.

Fig. 10. Qualité d'eau physico-chimique saisonnière dans les rivières Nam Theun (boîte à moustaches : NTH3, lignes continues : NTH4, lignes discontinues : NTH7) et Nam Phao (lignes pointillées : NPH1) à l'aval du barrage de Nakai. Les lignes en gris indiquent les valeurs moyennes mesurées entre 2005 et mars 2008 à NTH3.

$43.9 \%\left(7.23 \pm 1.14 \mathrm{mgO}_{2} \cdot \mathrm{L}^{-1}\right.$ or $87.6 \pm$ $12.6 \%$ in average) even immediately after the impoundment. Except during some periods, oxygen concentration was similar to that observed in the Nam Phao River $\left(7.97 \pm 0.87 \mathrm{mgO}_{2} \cdot \mathrm{L}^{-1}\right.$ or $94.3 \pm 6.7 \%$ in average). The daily (night and day) variation range of $\mathrm{DO}$ concentration varied between 0.5 and $2 \mathrm{mg} \cdot \mathrm{L}^{-1}$. Lowest $\mathrm{pH}$ values downstream the Nakai Dam (NTH3) occurred immediately after the impoundment for approximately the first 4 seasons and then tended to increase regularly up to 2013. Except during the 2009-2010 CD, 2010 WD and 2010 WW seasons, there was no difference in $\mathrm{pH}$ between the downstream stations. Conductivity in released water was the highest the first months after impoundment. It decreased between 2008 and the WW 2009 season and remained constant afterwards. Conductivity in the Nam Phao River was higher than in the reservoir at NTH3, as well as some major anions and cations $\left(\mathrm{SO}_{4}{ }^{2-}\right.$, $\mathrm{Cl}^{-}, \mathrm{Na}^{+}$) (Tab. SI-III). 
$\mathrm{NO}_{3}{ }^{-}$concentration increased in the Nam Theun River from NTH3 to NTH4 and then to NTH7 (Figs. 9 and 10). These concentrations were far below those observed in the Yangtze downstream the Three Gorges Dam, about $1.5 \mathrm{mgN}^{-1}$ (Müller et al., 2008), three years after dam closure. $\mathrm{NH}_{4}{ }^{+}$concentrations were of the same order of magnitude between the Nam Theun River and the Yangtze downstream of the dam (0.07 mgN.L-1; Müller et al., 2008). Higher total phosphorus and total suspended solids in the Nam Phao River induced an increase of these two compounds in the downstream Nam Theun River as compared to the low concentrations measured immediately downstream of the dam since the impoundment. As in the reservoir, the downstream concentration of total dissolved iron was high between the impoundment and the 2009-2010 CD season as compared to the tributaries. At NTH3, between April 2008 and March 2010 (commissioning), concentrations ranged from 0.02 to $4.81 \mathrm{mgFe} . \mathrm{L}^{-1}$ for an average value of $1.38 \mathrm{mgFe} \cdot \mathrm{L}^{-1}$. Since March 2010 , concentrations at NTH3 have fallen between 0.03 and $0.69 \mathrm{mgFe} . \mathrm{L}^{-1}$ for an average of $0.32 \mathrm{mgFe} . \mathrm{L}^{-1}$. These values were below those observed downstream from the Three Gorges Dam three years after impoundment: $1.3 \mathrm{mg}^{-1}{ }^{-1}$ (Müller et al., 2008).

\subsection{Downstream of the Power House}

The physico-chemistry of the water released in the tailrace channel (TRC1, Figs. 11 and 12) mimicked measurements at RES9 (Figs. 3 to 5). For all the parameters, except conductivity, no change occurred with time between the first significant releases (March 2010) and 2013. No peak can be observed during the first months after commissioning. Water temperature $\left(24.1 \pm 2.3^{\circ} \mathrm{C}\right.$ in average) had the same seasonal pattern with the lowest values during the $C D$ season $(22.1 \pm$ $1.8^{\circ} \mathrm{C}$ ) and the highest values during the WW season $\left(25.3 \pm 1.2^{\circ} \mathrm{C}\right)$. The regulating pond had no effect on water temperature and dissolved oxygen (no stratification, Fig. 13) and no temperature change occurred between TRC1 and $\mathrm{DCH} 4$. The lowest oxygen concentration at TRC1 was $0.8 \mathrm{mgO}_{2} \cdot \mathrm{L}^{-1}$ during the $2010 \mathrm{WW}$ season and the annual average concentration was $5.6 \pm 1.9 \mathrm{mgO}_{2} \cdot \mathrm{L}^{-1}$. Before reaching the Xe Bangfai River, oxygen in the Downstream Channel was similar to that measured upstream in this river $\left(8.2 \pm 0.7 \mathrm{mgO}_{2} \mathrm{~L}^{-1}\right.$ at DCH4 and $7.5 \pm$ $0.8 \mathrm{mgO}_{2} \cdot \mathrm{L}^{-1}$ at $\mathrm{XBF} 1$ ). The oxygen concentrations in the $\mathrm{Xe}$ Bang Fai River were similar at all stations upstream and downstream of the confluence with the Downstream Channel (XBF1, XBF2 and XBF3) which is consistent with the low average biological oxygen measured at XBF2 $(0.7 \pm$ $\left.0.3 \mathrm{mgO}_{2} \cdot \mathrm{L}^{-1}\right)$. The water temperature in the Downstream Channel was always lower than the one measured in the upstream Xe Bangfai River. The difference can reach $5{ }^{\circ} \mathrm{C}$. As a consequence, it decreased the temperature of the Xe Bangfai River during the WD season. During the WW season, no significant difference in water temperature was recorded due to high Xe Bangfai River watershed runoff buffering the Downstream Channel discharge. $\mathrm{pH}$ 


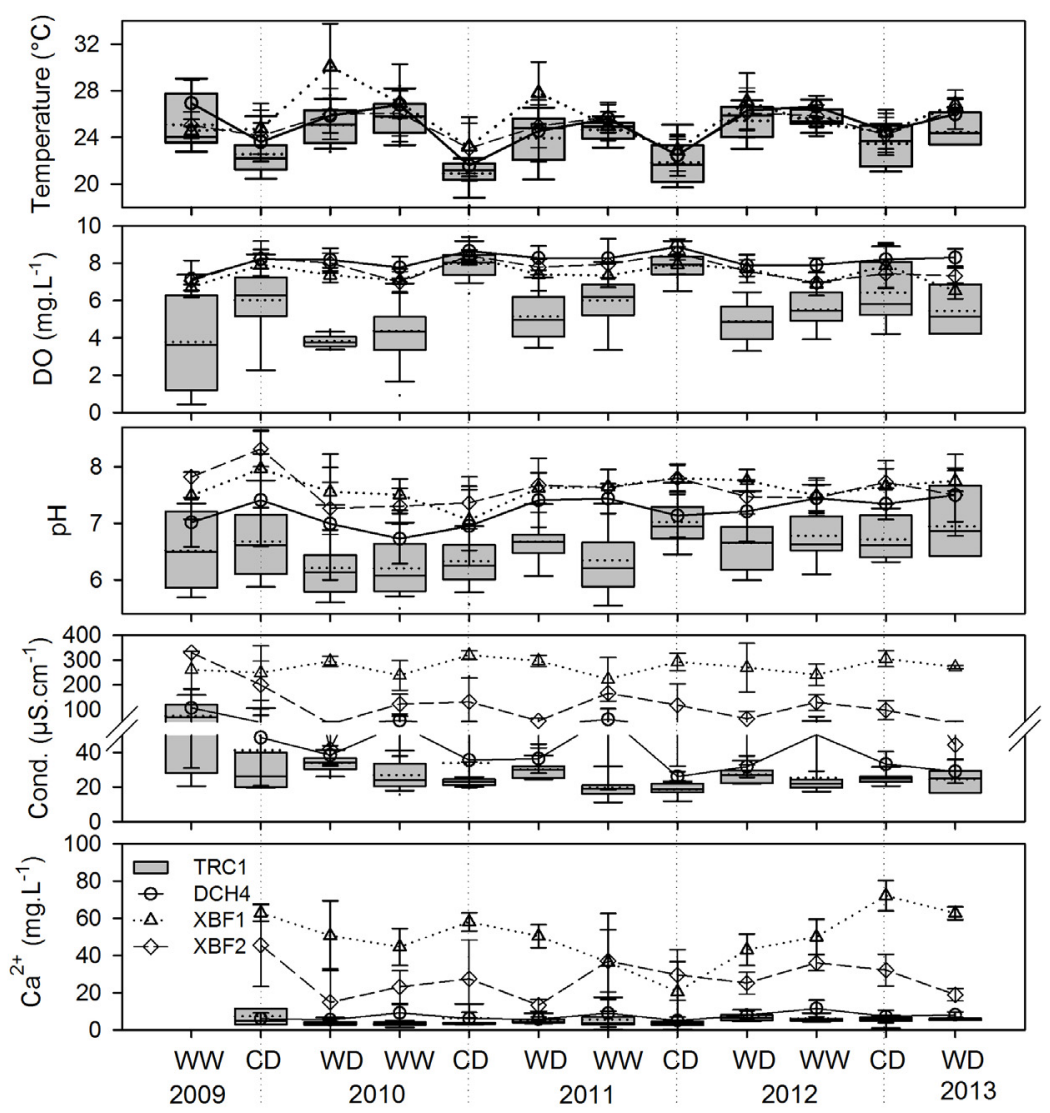

Fig. 11. Seasonal physico-chemical water quality in the tailrace (TRC1: box plots) and downstream (DCH1: continuous lines and DCH4: dotted lines) channels (left-hand side) and in the Xe Bangfai River (XBF1: box plots, XBF2: continuous lines and XBF3: dotted lines) (right-hand side). The dark grey lines indicate the average values measured between 2005 and March 2008 at XBF2 (WW: warm-wet season).

Fig. 11. Qualité d'eau physico-chimique saisonnière dans le canal de fuite (TRC1 : boîtes à moustaches) et dans le canal aval ( $\mathrm{DCH} 1$ : lignes continues et $\mathrm{DCH} 4$ : lignes pointillées) (à gauche) et dans la rivière Xe Bangfai (XBF1 : boîtes à moustaches, XBF2 : lignes continues et XBF3 : lignes pointillées) (à droite). Les lignes en gris indiquent les valeurs moyennes mesurées entre 2005 et mars 2008 à XBF2 (WW : saison chaude et humide).

values slightly increased from TRC1 $(6.53 \pm 0.58$ in average) to $\mathrm{DCH} 4$ $(7.20 \pm 0.59)$. No changes were observed in the Xe Bangfai River from XBF1 to XBF2. Difference of conductivity between the Downstream Channel and the Xe Bangfai was high. At TRC1 and in the Downstream Channel - DCH1 and $\mathrm{DCH} 4$-, the average conductivity was 31,28 and $41 \mu \mathrm{S} . \mathrm{cm}^{-1}$, respectively. In the Xe Bangfai River upstream the confluence (XBF1), the 


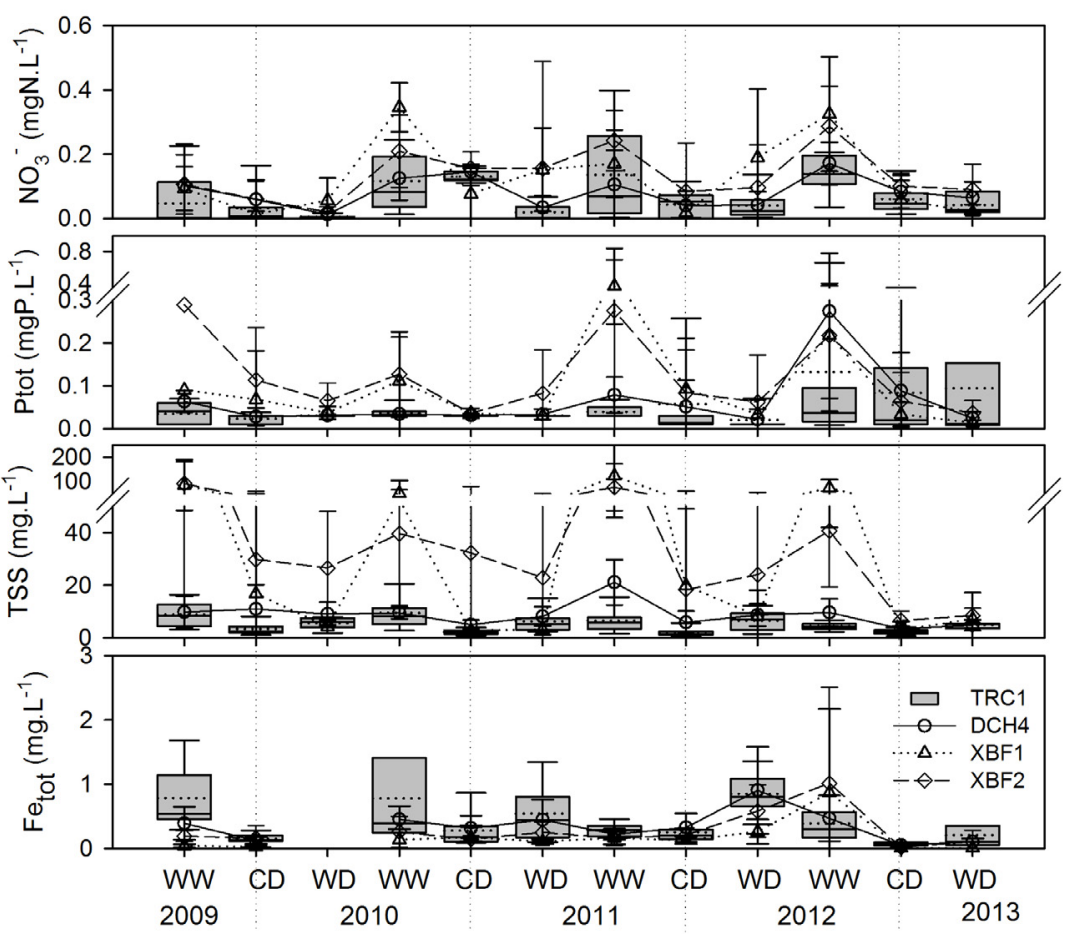

Fig. 12. Seasonal physico-chemical water quality in the tailrace (TRC1: box plots) and downstream (DCH1: continuous lines and DCH4: dotted lines) channels (left-hand side) and in the Xe Bangfai River (XBF1: box plots, XBF2: continuous lines and XBF3: dotted lines) (right-hand side). The dark grey lines indicate the average values measured between 2005 and March 2008 at XBF2 (WW: warm-wet season).

Fig. 12. Qualité d'eau physico-chimique saisonnière dans le canal de fuite (TRC1 : boîtes à moustaches) et dans le canal aval ( $\mathrm{DCH} 1$ : lignes continues et $\mathrm{DCH} 4$ : lignes pointillées) (à gauche) et dans la rivière Xe Bangfai (XBF1: boites à moustaches, XBF2 : lignes continues et XBF3 : lignes pointillées) (à droite). Les lignes en gris indiquent les valeurs moyennes mesurées entre 2005 et mars 2008 à XBF2 (WW : saison chaude et humide).

average value was $272 \mu$ S.cm ${ }^{-1}$ showing clear seasonal variations (decrease during the WW season). Differences in concentrations of $\mathrm{Ca}^{2+}$ and other major cations/anions were also observed between the same stations (Fig. 11, Tab. SI-IV). Between XBF1 and XBF2, average concentrations of $\mathrm{Ca}^{2+}$ and $\mathrm{Mg}^{2+}$ decreased by $48 \%$ and $50 \%$ respectively.
The same seasonal pattern as in the reservoir (RES9) can be observed at TRC1 for $\mathrm{NO}_{3}^{-}$(Fig. 12) and $\mathrm{NH}_{4}{ }^{+}$. Almost no change occurred in the Downstream Channel for these two parameters. $\mathrm{NO}_{3}{ }^{-}$values are of the same order of magnitude between the channel and the river. On the contrary, $\mathrm{NH}_{4}{ }^{+}$concentrations in the upstream Xe Bang Fai were lower than those in 


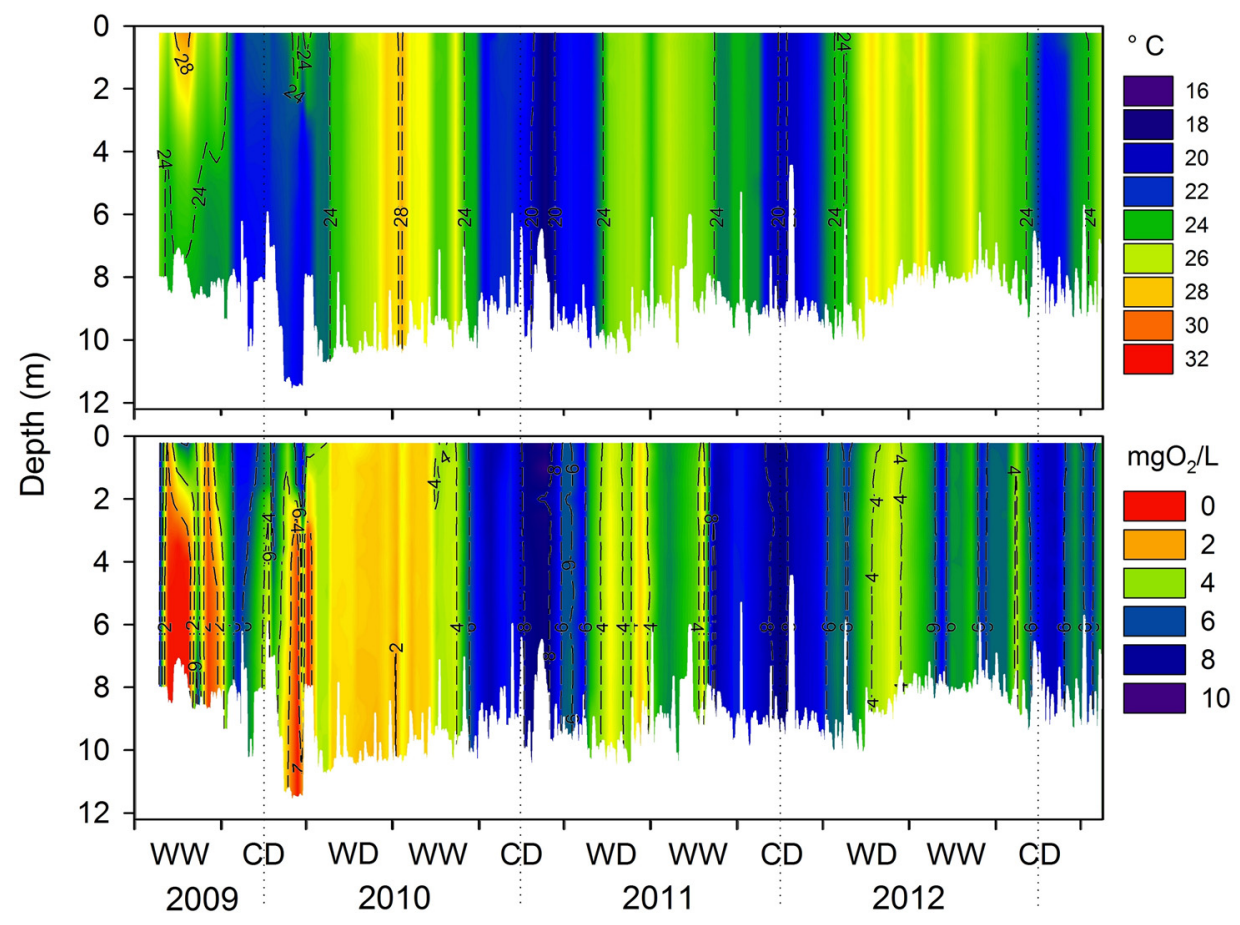

Fig. 13. Water temperature $\left({ }^{\circ} \mathrm{C}\right)$ and dissolved oxygen $\left(\mathrm{mg}^{\mathrm{L}} \mathrm{L}^{-1}\right)$ profiles in the regulating pond (REG1) between 2009 and 2013.

Fig. 13. Profils de température de l'eau $\left({ }^{\circ} \mathrm{C}\right)$ et de l'oxygène dissous $\left(\mathrm{mg} \cdot \mathrm{L}^{-1}\right)$ dans le bassin de démodulation (REG1) entre 2009 et 2013.

the Downstream Channel. Downstream of the confluence, the impact of the released water became negligible after 2011. Like for $\mathrm{NO}_{3}{ }^{-}$, the dynamics in the reservoir explained well the total $P_{\text {tot }}$ concentrations at TRC1. On average, $\mathrm{P}_{\text {tot }}$ concentration in the Downstream Channel $\left(0.07 \pm 0.18 \mathrm{mgP} . \mathrm{L}^{-1}\right.$ at $\mathrm{DCH} 4)$ was lower than at XBF1 $\left(0.12 \pm 0.21 \mathrm{mgP}^{-\mathrm{L}^{-1}}\right)$. TSS concentrations in the released water (TRC1) were low $\left(5.1 \pm 4.3 \mathrm{mg} \cdot \mathrm{L}^{-1}\right.$ on average) as compared to concentrations in the upstream Xe Bangfai River (35.4 \pm $74.4 \mathrm{mg} \cdot \mathrm{L}^{-1}$ on average). In addition to a low average concentration, no TSS peak occurred as at TRC1. As a consequence, high TSS values measured during the WW seasons were reduced downstream the confluence. However, concentrations in the Downstream Channel were usually higher than in the upstream Xe Bangfai during the CD $\left(7.6 \pm 17.4 \mathrm{mg} \cdot \mathrm{L}^{-1}\right.$ and $21.1 \pm$ $32.1 \mathrm{mg} . \mathrm{L}^{-1}$ in average at XBF1 and $\mathrm{XBF} 2$, respectively) and WD (5.2 \pm $6.1 \mathrm{mg} \cdot \mathrm{L}^{-1}$ and $19.7 \pm 22.3 \mathrm{mg} \cdot \mathrm{L}^{-1}$ ) seasons. The range of TSS concentration decreased from [1.3-529 mg. $\mathrm{L}^{-1}$ ] at XBF1 to [3.8-306 mg. $\left.\mathrm{L}^{-1}\right]$ at XBF2 


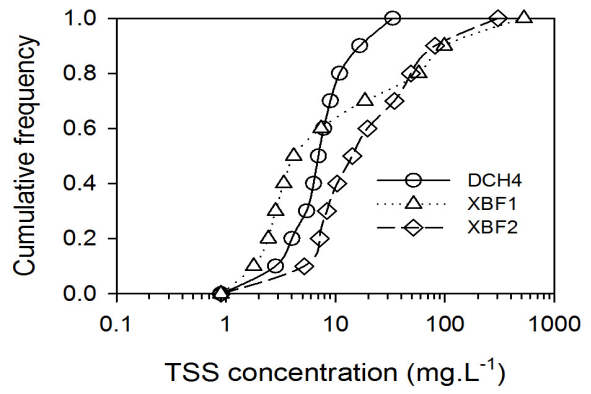

Fig. 14. Cumulative frequency of total suspended solids concentrations in the Downstream Channel (DCH4) and in the Xe Bangfai River (XBF1 and XBF2).

Fig. 14. Fréquence cumulée des concentrations des matières en suspension dans le canal aval $(\mathrm{DCH} 4)$ et dans la rivière Xe Bangfai (XBF1 et XBF2).

between March 2010 and March 2013. Moreover, the cumulative frequency of TSS concentration in the Downstream Channel and in the $\mathrm{Xe}$ Bangfai River (Fig. 14) shows clearly that the occurrences of measurements below $50 \mathrm{mg} \cdot \mathrm{L}^{-1}$ increased at XBF2 as compared to XBF1. TSS concentrations were below $5 \mathrm{mg} \cdot \mathrm{L}^{-1}$ for about $55 \%$ of the time at XBF1 while this percentage dropped to $10 \%$ at XBF2. On the contrary, high values

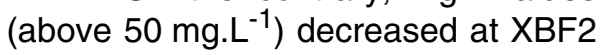
as compared to XBF1.

\section{DISCUSSION}

\subsection{From a riverine system to a lacustrine system}

The watershed surface areas of three studied tributaries (Nam Xot,
Nam Theun and Nam On Rivers) correspond to about $14 \%, 32 \%$ and $20 \%$ of the total watershed surface area respectively. It means that only about $66 \%$ of the water inputs are characterized assuming similar specific discharges for the watersheds. The remaining $34 \%$ are mostly located in the same eastern mountainous area, mainly covered by forests. Physicochemistry in these upstream rivers was typical of sub-tropical pristine rivers found in the same environment (geology, land use, hydrometeorology, morphology...), characterized by high water temperature, high oxygen content, low conductivity and low nutrients loads (Lewis, 2008). Small differences were measured between tributaries for conductivity, major anions and cations and dissolved organic carbon. Differences in the local geology, pedology and land use of the three specific watersheds may explain these dissimilarities. Moreover, differences at the Nam On River station at some periods of the year could be attributed to the fact that the monitoring station is under the influence of the reservoir during the WW season. Seasonal differences of air temperature $(24.8,24.6$ and $20.2{ }^{\circ} \mathrm{C}$ for the WD, WW and CD seasons, respectively), rainfall (7.2, 13.3, $\left.0.3 \mathrm{~mm} . \mathrm{d}^{-1}\right)$ and discharges $\left(120,512\right.$ and $\left.83 \mathrm{~m}^{3} . \mathrm{s}^{-1}\right)$ induced significant changes of water temperature between the WD (warm water) and CD (cold water) seasons. More surprisingly, seasonal differences for the other parameters were low. Only a slight seasonal dilution/concentration effect seems to impact parameters such as conductivity, nitrates and other major anions and cations. 
As compared to the former Nam Theun River, the dam closure in April 2008 induced a drastic modification of the physical aquatic environment. The residence time changed from a few hours before the impoundment to an average of 168 days after it. As the residence time, water depth and surface of flooded soils increased, a thermal chemical stratification appeared. Such stratification is commonly observed in tropical and sub-tropical reservoirs (Richard et al., 2005). The stratification/destratification processes are mainly driven by temperature and wind. Other parameters can also partly control these processes. For instance, in a wooded area, trees may have a significant effect on the circulation patterns of the reservoir. In the Nam Ngum reservoir in Laos, standing trees almost completely eliminate wind-generated turbulence and consequently reduce the extent of mixing (Baxter, 1977). It may explain why the impact of annual destratification is lower in the Nam Malou area (RES3) initially covered by forest (Descloux et al., 2011). Contrary to the Petit Saut Reservoir in French Guiana (Richard et al., 1997; 2005), this stratification weakened then disappeared each year during the $C D$ season due to a drop of air temperature (Descloux et al., this issue-a). Particularly intense flood events such as in August 2009 or 2011 resulted also in an almost total homogenisation of the reservoir even in its deepest parts during the WW season. During the 20122013 CD season, the destratification was delayed. It was due to a higher air temperature in November and December 2012 than during the previous years $\left(23.8 \pm 1.3^{\circ} \mathrm{C}\right.$ and $21.2 \pm 2.7^{\circ} \mathrm{C}$ in November and December 2012 as compared to the 2008-2011 average for the same months: $21.6 \pm 3.2^{\circ} \mathrm{C}$ and $\left.19.0 \pm 3.4^{\circ} \mathrm{C}\right)$.

The thermal stratification induced a chemical stratification. Compounds produced from the decomposition of organic matter stock $\left(\mathrm{NH}_{4}^{+}, \mathrm{PO}_{4}^{3-}\right.$, $\left.\mathrm{CO}_{2}, \mathrm{CH}_{4} \ldots\right)$ or diffusing in their reduced forms from the soils ( $\mathrm{Fe}, \mathrm{Mn}$...) accumulated in the hypolimnion while dissolved oxygen was rapidly consumed. At the surface, wind-induced reaeration of the water and photosynthetic activity (Martinet et al., this issue), also revealed by an increase of $\mathrm{pH}$ values in the epilimnion, insured a correct oxygenation level in the uppermost meters. The consequence of the annual destratification is a homogenisation of the water column and a distribution of compounds between bottom and surface waters, including oxygen. Bottom concentrations of reduced compounds decreased suddenly, while surface concentrations increased. Most of the time, the oxidation of reduced compound precluded a significant increase in oxygen concentration in the hypolimnion. However, during special events such as the August 2011 major flood which provoked dam spilling and the dilution of water compounds, the deepest parts of the reservoir can be sometimes oxic as already observed for the Petit Saut Reservoir in 2000 (Richard et al., 2005). The destratification delay observed during the 2012-2013 CD season, coupled with low water inputs in 2012 as compared to the other years (Descloux et al., this issue-a), have significant impacts on physico-chemistry with an increase of the peak of concentrations of reduced 
compounds in the hypolimnion, underlying the major influence of hydrology on physico-chemistry.

Between April 2008 and March 2010 , discharges at the dam were not drastically reduced as compared to tributaries input (to insure a moderated increase of water level in the reservoir; Descloux et al., this issue-a). As a consequence, water renewal was still efficient (except in some isolated areas like RES3 for instance) and it may explain why (i) no major degradation peak was observed and (ii) spatial heterogeneities were limited. The behaviour of the NT2 Reservoir changed since March 2010 with the beginning of normal operations. The water level decreased for the first time and waters coming from the tributaries were preferentially directed towards the water intake $(Q$ mean water intake $=$ $213.0 \mathrm{~m}^{3} . \mathrm{s}^{-1}$ ) rather than to the Nakai $\operatorname{Dam}\left(Q\right.$ mean Nakai $\left.=35.1 \mathrm{~m}^{3} \cdot \mathrm{s}^{-1}\right)$ as shown by numerical simulations (Chanudet et al., 2012). The residence time in the zone between RES1 and RES4 (North West) of the reservoir increased drastically as compared to the zone between RES4 and RES8 (South East) and spatial heterogeneities amplified. Close to the water intake (RES9), the lower residence time and the permanent mixing due to high current velocities and turbulences induced an almost continuous oxygenation of the water column. The other physico-chemical parameters in this zone also improved more rapidly as evidenced by conductivity profiles for instance. At the same time, highest $\mathrm{NH}_{4}{ }^{+}, \mathrm{Fe}, \mathrm{GHG}$ (Serça et al., this issue) concentrations were then measured in the North West zone (RES1). In this zone, enhanced oxygen consumption due to the degradation of the initial carbon stock also probably explains the spatial differences. The former above ground biomass was denser in this area mainly covered by forests before the impoundment than in the South East zone, formerly covered by grassland and agricultural plots (Descloux et al., 2011).

\subsection{The Nam Theun River downstream Nakai Dam}

\subsubsection{Impacts of the NT2 project on the physico-chemical parameters}

During the first two years, average discharge of the Nam Theun River downstream of the Nakai Dam was reduced by $19 \%\left(193 \mathrm{~m}^{3} . \mathrm{s}^{-1}\right.$ between April 2008 and March 2010). During this period, no anoxia was measured in the downstream Nam Theun River close to the dam or $60 \mathrm{~km}$ away from it, contrary to Petit Saut Reservoir (Gosse \& Grégoire, 1997; Richard et al., 1997). No sag curve effect was observed because the biological and chemical oxygen demands were low and also because turbulences and current velocities are high in the river. In average, the measurements were done at the middle of the day before and after the impoundment. Therefore, it is assumed that there was no significant bias due to water warming or diurnal cycles due to primary production and respiration and that pre and post impoundment concentrations can be compared directly. The average oxygen concentration was reduced by only $7 \%$ at NTH3 as compared to the preimpoundment concentration (7.92 \pm 
$0.97 \mathrm{mgO}_{2} \cdot \mathrm{L}^{-1}$ or $93.2 \pm 6.1 \%$ in average, Fig. SI-6). The higher concentration of reduced compounds $\left(\mathrm{NH}_{4}{ }^{+}\right.$, $\mathrm{Fe} . .$.$) or \mathrm{CO}_{2}$ as compared to the preimpoundment situation (for instance + $360 \%$ for total dissolved iron in average) was probably responsible for the decrease of $\mathrm{pH}$ as compared to before 2008 (- $0.45 \mathrm{pH}$ units in average). Surprisingly, the increase in reduced compounds did not affect the conductivity which was similar to pre-impoundment measurements $\left(36 \pm 15 \mu \mathrm{S} . \mathrm{cm}^{-1}\right.$, Fig. SI-6). The effect of the reservoir on the downstream river is a reduction of $\mathrm{NO}_{3}{ }^{-}$as compared to the pre-impoundment situation $\left(0.12 \pm 0.09 \mathrm{mgN}^{-1} \mathrm{~L}^{-1}\right)$. $\mathrm{NO}_{3}{ }^{-}$consumption for primary production or denitrification may explain it.

After commissioning (March 2010), downstream physico-chemical water quality evolved compared to the two previous years $\left(\mathrm{pH}\right.$, conductivity, $\mathrm{NH}_{4}{ }^{+}$, TSS, $\left.\mathrm{Fe}_{\text {tot }}\right)$ for two reasons. Since March 2010, the discharge was only constituted by the riparian release $\left(2 \mathrm{~m}^{3} \cdot \mathrm{s}^{-1}\right.$, Descloux et al., this issue-a), taken from the surface of the reservoir. Moreover, the riparian release flow through a hollow jet valve which promotes reaeration and degassing (Descloux et al., this issue-b, Serça et al., this issue). The second reason is the general evolution of physicochemical parameters in the reservoir. However, during the Nakai Dam spillage (WW seasons), released water may originate from the whole water column (radial gates opened), conditions favouring oxygen concentration decrease. As compared to the preimpoundment situation (Fig. SI-6), no major evolution of the average physico-chemistry immediately downstream
Nakai Dam occurred during this period for dissolved oxygen, $\mathrm{pH}, \mathrm{P}_{\text {tot }}$ or TSS. Conductivity decreased as compared to the situation prior to the impoundment. This latter observation is corroborated by the decrease of some major anions and cations, such as $\mathrm{SO}_{4}{ }^{2-}, \mathrm{Cl}^{-}, \mathrm{Na}^{+}$and $\mathrm{Mg}^{2+}$, between pre and post-impoundment measurements. $\mathrm{NO}_{3}{ }^{-}$concentration has been also reduced. This could be attributed either to consumption for primary production or to a higher denitrification. More significant changes have been observed in further downstream stations. Due to the reduction of the Nam Theun River discharge, the contribution of its main tributaries (including Nam Phao) increased, and physicochemical water quality changed especially for conductivity or nutrient loads. However, the geological nature of the various sub-watersheds is close and changes were not drastic.

\subsubsection{Effect of the flushing} of the reservoir before commissioning: the case of iron

During the first years, serious issues regarding iron occurred: (i) water release into the Nam Theun River was limited due to high iron level in the water (water quality requirement in the downstream reservoir), (ii) ironrich biofilm deposit in the headrace tunnel and in the penstock increased head loss (Pécastaings et al., same issue). About $10.7 \times 10^{9} \mathrm{~m}^{3}$ of water left the reservoir at the dam for an average reservoir volume of $3.18 \times 10^{9} \mathrm{~m}^{3}$. It means that the reservoir was flushed 3.4 times before commissioning. A one-box mass balance calculation was 
performed for total dissolved iron. River fluxes were calculated in the Nam Theun River immediately downstream of the Nakai Dam (NTH3) and upstream of the reservoir (NTH2). Total incoming iron flux was then extrapolated to the whole watershed by multiplying by 3.12 (ratio between the total watershed and that of the Nam Theun River at NTH2). Between April 2008 and March 2010, about $4470 \pm$ 900 tons of iron entered the reservoir and $24600 \pm 5200$ tons were exported. Moreover, in March 2010, the stock of total dissolved iron in the reservoir $\left(3.96 \times 10^{9} \mathrm{~m}^{3}\right)$, was estimated at 4080 tons (from an average iron concentration measured in all the stations at all the depths). The amount of iron released from the flooded soils was $24200 \pm 5300$ tons. This figure might be underestimated since it does not take into account the potential iron precipitation between the dam and NTH3 (few minutes) as only the dissolved fraction was measured. Total iron concentration in top soils prior to the impoundment ranged between $13.9 \mathrm{~g}^{\mathrm{kg}}{ }^{-1} \mathrm{dm}$ in forests and $44.6 \mathrm{~g} . \mathrm{kg}^{-1} \mathrm{dm}$ in agricultural soils (Chanudet \& Descloux, 2008). Given the land use distribution in the reservoir area (Descloux et al., 2011), the total iron density in the uppermost $10 \mathrm{~cm}$ amounted to 945000 tons ( $21 \mathrm{tFe}^{\mathrm{h}} \mathrm{h}^{-1}$ ). With similar total iron concentration in tropical soils, Peretyazhko \& Sposito (2005) found that the poorly crystalline $\mathrm{Fe}(\mathrm{III})$ hydro(oxides) represented about $5 \%$ of the total iron. Rumpel et al. (2006) measured similar ratios in some Lao soils $(6.7 \%$ in average) for iron concentrations in surface ranging between 28.4 and 53.9 g. kg ${ }^{-1}$. For the
Nam Theun 2 soils, we can assume an amount of poorly crystalline $\mathrm{Fe}(\mathrm{III})$ hydro(oxides) of 47300 tons in the uppermost $10 \mathrm{~cm}$. This fraction is likely to be preferentially reduced in iron (II) and released from the soils when reducing conditions prevail after flooding. The thickness of the soil layer from which iron is mobilized cannot be estimated with this mass balance calculation and no conclusion can be drawn on the remaining iron likely to be released in the water column.

Out of the $11240 \pm 1240$ tons that left the reservoir since commissioning (March 2010), only $1980 \pm 320$ tons (18\%) have been exported in the Nam Theun River. The remaining $82 \%$ flowed through the Power House and the Downstream Channel. Since the impoundment, $35870 \pm 5440$ tons have been released from the reservoir, $69 \%$ during the two first years.

\subsection{The Xe Bangfai watershed}

\subsubsection{From a crystalline to a calcareous watershed}

Significant water releases through the Power House started in March 2010 (Descloux et al., this issue-a). The high oxygen concentration in the reservoir close to the intake (RES9) due to permanent vertical mixing led to an average oxygen concentration in the tailrace channel of $5.6 \pm 1.9 \mathrm{mgO}_{2} \cdot \mathrm{L}^{-1}$. Since March 2010, the residence time in the regulating pond dropped to only $5.4 \mathrm{~h}$; too short to allow for any significant physico-chemical evolutions. Oxygen concentration increased when passing the regulating dam and the aeration weir (Descloux et al., this 
issue-b) and reached a typical natural concentration value in such a sub-tropical environment (Lewis, 2008) before reaching the Xe Bangfai River (similar to upstream rivers). There was no sag curve effect in the Downstream Channel. Downstream of the confluence (XBF2), the average oxygen concentration after the commissioning $(7.8 \pm$ $0.4 \mathrm{mgO}_{2} \cdot \mathrm{L}^{-1}$ ) was similar to the concentration between 2005 and 2008 $\left(7.9 \pm 1.1 \mathrm{mgO}_{2} \cdot \mathrm{L}^{-1}\right)$ (NTPC, unpublished data), assuming the average sampling hours were the same for these two periods. Gosse \& Luck (2003) showed that the diurnal variation could reach up to $1,5 \mathrm{mg} \cdot \mathrm{L}^{-1}$ near XBF2 before impoundment.

Because of the geology of the Nam Theun River and watershed (mainly crystalline; NTPC, 2005), turbinated water had a low conductivity. This conductivity did not increase along the Downstream Channel. The Xe Bangfai River watershed mainly consists of limestone (NTPC, 2005). It explains the higher conductivity in this river. One of the main consequences of the project was a drop of conductivity downstream of the confluence. On average, values at XBF2 were divided by a factor of three as compared to those at XBF1 and those prior to the project $(291 \pm$ $57 \mu$ S.cm ${ }^{-1}$ at XBF2 between 2005 and 2008 versus $102 \pm 64 \mu \mathrm{S} . \mathrm{cm}^{-1}$ since March 2010). Contrary to the reservoir where high conductivity values were related to high concentration of reduced compounds, in the Xe Bangfai River, conductivity was mainly driven by major anions and cations (linear regression at XBF2 between conductivity and $\mathrm{Ca}^{2+}$ concentration, $\mathrm{r}^{2}=0.71$ ). Another consequence of the diversion of reservoir water in the Xe Bangfai is the reduction of the concentration of these ions in the Xe Bangfai River as compared to the pre commissioning situation. This modification of the water chemical composition may have significant impacts on hydrobiology (Allan \& Castillo, 2007; Attwood \& Cottet, this issue) although the nutrient loads (except $\mathrm{NH}_{4}^{+}$) was reduced downstream of the confluence as compared to the situation prior to the project. The average biological oxygen demand at XBF2 was similar before $\left(0.7 \pm 0.3 \mathrm{mgO}_{2} \cdot \mathrm{L}^{-1}\right.$ measured between 2005 and 2008, $2.8 \mathrm{mgO}_{2} \cdot \mathrm{L}^{-1}$ measured in April 2001 (Goss \& Luck, 2003) and after commissioning (1.0 \pm $\left.0.9 \mathrm{mgO}_{2} \cdot \mathrm{L}^{-1}\right)$. The high buffering capacity of the water in the upstream Xe Bangfai River as compared to water from the reservoir (low carbonate concentration), also precluded a significant decrease in $\mathrm{pH}$ value between the pre $(7.63 \pm 0.33)$ and post $(7.56 \pm 0.49)$ commissioning situations (Allan \& Castillo, 2007).

\subsubsection{The smoothing effect of the project on TSS concentration in the Xe Bangfai River}

At the annual scale, the project has no major impact on TSS fluxes between upstream tributaries and turbinated water. Between March 2010 and March 2013, $106.8 \pm 19.3 \mathrm{kt}$ of TSS entered into the reservoir via the tributaries and $112.6 \pm 7.8 \mathrm{kt}$ left it via the Power House. The absence of difference between inputs and outputs, - $5.8 \pm$ $20.8 \mathrm{kt}$, indicates that the net sediment storage (input-output) in the reservoir is low. However, no information about 


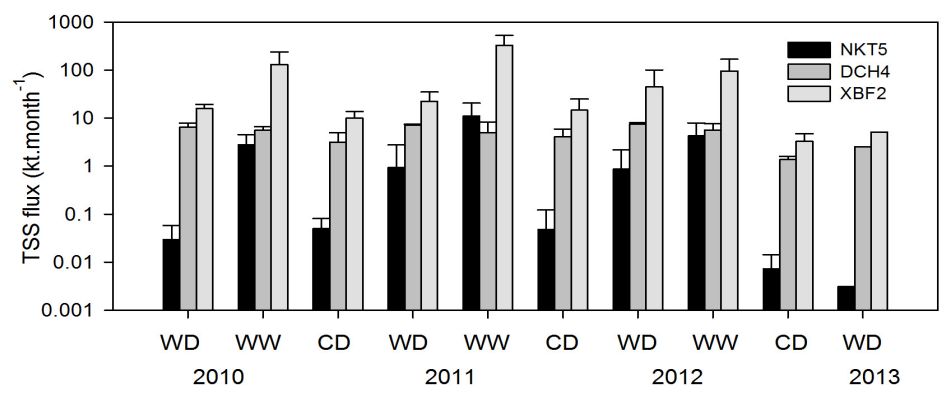

Fig. 15. Seasonal fluxes of total suspended solids concentrations in the Nam Kathang River (NKT5), the Downstream Channel (DCH4) and the Xe Bangfai River (XBF2).

Fig. 15. Flux saisonniers de matières en suspension dans la rivière Nam Kathang (NKT5), dans le canal aval (DCH4) et dans la rivière Xe Bangfai (XBF2).

the nature and the origin of TSS is provided and a shift of the composition between incoming and released TSS is likely. Out of the $112.6 \mathrm{kt}$ exported from the reservoir, a fraction is constituted by in situ organic production and it is likely that a similar fraction of TSS entering the reservoir through the rivers settled down in the reservoir. Moreover, autochthonous organic matter was also likely to sediment.

The project had a significant impact on the seasonal distribution of TSS concentrations, especially in the Xe Bangfai River (Fig. 12) inducing a reduction of the range of the extreme values. Since March 2010, minimal TSS values were measured at $\mathrm{XBF} 1$ during the $C D$ and WD seasons when the discharges were lower (Descloux et al., this issue-a). These low TSS values at XBF1 were probably representative of the pre-commissioning situation at XBF2 since the contribution of the Nam Kathang River was low during these seasons. Since the commission- ing, the release of reservoir water into the Xe Bangfai River via the Downstream Channel induced an increase of the lowest concentrations and of the flux measured during these two seasons. At an annual scale, the TSS fluxes in the Downstream Channel (DCH4) and in the Nam Gnom (NKT5) were $60.4 \pm 3.6 \mathrm{kt}^{-y^{-1}}$ and $25.8 \pm$ $6.2 \mathrm{kt} . \mathrm{yr}^{-1}$, respectively. It represented respectively $7 \%$ and $3 \%$ of the annual flux at XBF2 $\left(861 \pm 146 \mathrm{kt}^{-y r^{-1}}\right)$. During the $C D$ and WD seasons, the contribution of the Downstream Channel to the flux at XBF2 increased up to $41 \%$ (33.6\% in average) (Fig. 15) while it did not exceed $4 \%$ (1.0\% in average) for the Nam Gnom. During this period, TSS concentrations at XBF2 were above the concentrations at XBF1, NKT5 and DCH4. It was likely due to the increase of the discharge during these seasons as compared to the precommissioning situation (Descloux et al., this issue-a). The highest discharges mobilized probably more particles from 
the river beds or from riparian soils as compared to the same periods before commissioning. This excess flux has been estimated at $0.8 \pm 0.2 \mathrm{kt}^{\mathrm{month}}{ }^{-1}$ i.e. $6.4 \pm 1.8 \mathrm{kt}^{-y r^{-1}}$ between March 2010 and March 2013 (assuming a TSS concentration at XBF2 as the discharge-weighted average between concentrations at XBF1, NKT5 and $\mathrm{DCH} 4)$. It represents about $0.7 \%$ of the total flux at XBF2.

Maximal TSS values were measured during floods (WW season). During these events, TSS concentrations and fluxes (Fig. 15) in the Downstream Channel were much lower than in the upstream Xe Bangfai River and the water released from the reservoir decreased the concentration in the downstream Xe Bangfai River (dilution effect). The average contribution of the Downstream Channel to the annual flux at XBF2 was only $3.9 \%$ on average during the WW seasons (3.3\% for the Nam Kathang River).

In the Xe Bangfai River, turbidity was strongly correlated to TSS ([TSS] $\left(\mathrm{mg} \cdot \mathrm{L}^{-1}\right)=0.83 \times$ turbidity $(\mathrm{NTU}), \mathrm{r}^{2}=$ $0.95)$. Turbidity plays a major role in ecological processes in aquatic systems (Allan \& Castillo, 2007; Davies et al., 2008) and its modification in the Xe Bangfai River as well as the modifications of the flow regime (current velocity, water level...) may also explain some of the observed hydrobiological changes (Davies et al., 2008; Attwood \& Cottet, this issue).

\subsection{Mid-term evolution}

Because of the temporal variations of physico-chemical water quality parameters due to a large extent to the reservoir hydrodynamics, it is difficult to reach conclusion of the intrinsic evolution of the water quality in the reservoir for all parameters. It may also be premature to state that the two degradation periods (immediately after impoundment and after commissioning) due to initial stocks (carbon, nutrients, iron...) in the soils and vegetation are the last ones and that a stable regime has already been reached. For some parameters, like the Secchi depth, dissolved oxygen, $\mathrm{pH}, \mathrm{NO}_{2}{ }^{-}$or $\mathrm{Fe}$, the improvement is obvious and will probably continue in the coming years. Measurements in water suggest that the releasable iron stock in soils was lower after 5 years. Measured iron concentrations during the first years will probably not be observed again in the future (no other source than sediments). For parameters also produced from an allochthonous source of organic matter ( $\mathrm{P}$ and $\mathrm{N}$ species) the conclusion is less evident. $\mathrm{NO}_{3}{ }^{-}$and $\mathrm{P}_{\text {tot }}$ did not exhibit significant changes from the impoundment (no peak) and observed values were close to those measured in the Nam Theun River prior to the project. DOC also remained stable during the 5 years. The probability to observe future significant concentration changes at the annual scale for these parameters is low. A strong relationship between $\mathrm{NH}_{4}{ }^{+}$and reservoir hydrodynamics exists, as evidenced by the highest concentrations measured during the 2012-2013 CD season due to a poor hydrology coupled with a delayed destratification as compared the previous years. The contributions of (i) the initial organic matter and nutrient stocks and (ii) the organic matter 
produced in situ or coming from the tributaries to $\mathrm{NH}_{4}{ }^{+}$production are currently unknown. It implies that high $\mathrm{NH}_{4}{ }^{+}$concentrations cannot be excluded in the future, especially at the end of a long stratified period.

In the Xe Bangfai River, potential physico-chemical changes due to a modification of the water in the reservoir have been offset by changes induced by the water diversion from a crystalline to a calcareous watershed. Downstream the confluence between the Downstream Channel and the Xe Bangfai River, new stable physicochemical conditions have been reached, significantly different from the pre-commissioning situation for some major parameters (conductivity, $\mathrm{Ca}^{2+}$, $\mathrm{Mg}^{2+}, \mathrm{TSS} \ldots$..).

\section{CONCLUSION}

The 5-year monitoring of the Nam Theun 2 system showed the effect of the impoundment on the aquatic system. New physico-chemical processes appeared since soils were flooded and water depth and its residence time increased. No major changes (no peaks) were observed in the reservoir as regard nutrients (except $\mathrm{NH}_{4}{ }^{+}, \mathrm{NO}_{2}{ }^{-}$), major anions or cations, etc. Bottom $\mathrm{Fe}_{\text {tot }}$ concentration increased during the first two years as compared to the pre-impoundment situation. The annual destratification that occurred in the reservoir led to a vertical homogenisation of the physico-chemical parameter in the water column. The temporal variations of water quality parameters, due to a large extent to the reservoir hydrodynamics, preclude definite conclusion regarding the intrinsic mid-term evolution of all physico-chemical parameters in the reservoir. The contribution of the initial stocks in vegetation and soils (carbon, nutrients, iron...) versus the allochthonous or autochthonous sources to the evolution of physico-chemistry remains for instance unknown. However, for some parameters, such as $\mathrm{Fe}_{\text {tot }}, \mathrm{NO}_{3}{ }^{-}, \mathrm{NO}_{2}^{-}$for instance, conclusions can be drawn on the fact that a rather stable water quality regime has probably been already reached. For other parameters, like oxygen or $\mathrm{pH}$, continuous evolution observed since the impoundment will probably last for the coming years.

In the Nam Theun River downstream of the dam, the physico-chemical water quality was slightly altered. Water always remained oxygenated and after a few months no further chemical changes had been observed and water quality was close to that measured in the reservoir tributaries or in the river before the dam construction. The special design of the water intake for the riparian release (surface water) probably explains these observations.

Water released in the Xe Bangfai River was also well oxygenated and low in reduced compounds for several reasons: (i) the design of the water intake and the headrace channel that ensures a mix of the whole water column rather than withdrawing bottom water only and (ii) the presence of several aeration. devices along the Downstream Channel. However, waters in the Downstream Channel and in the upstream Xe Bangfai River were different in terms of temperature and dissolved species $\left(\mathrm{Ca}^{2+}, \mathrm{Mg}^{2+}\right)$ and therefore conductivity. Peaks of concentrations sometimes 
observed in the upstream Xe Bangfai (TSS, $P_{\text {tot }}$ ) during floods are now smoothed. Other parameters (nitrogen, $\left.\mathrm{DOC}, \mathrm{Fe}_{\text {tot }}\right)$ were only marginally impacted by the diversion of the Nam Theun River into the Xe Bangfai River via the reservoir. Physico-chemical water quality in the coming years will probably not change significantly (stable regime) in this river.

\section{ACKNOWLEDGEMENTS}

This research was conducted at the Aquatic Environment Laboratory of Nam Theun 2 Power Company in Lao PDR whose Shareholders are Électricité de France, Lao Holding State Enterprise and Electricity Generating Public Company Limited. of Thailand. The authors would like to thank the Nam Theun 2 Power Company (NTPC) for providing the logistic support on site related to field activities and the Technical Division of NTPC, for providing key technical drawings. We are also grateful to the team of the Aquatic Environment Laboratory (AEL) for chemistry analyses and their help during field trips.

\section{REFERENCES}

Abril G., Guérin F., Richard S., Delmas R., Galy-Lacaux C., Gosse P., Tremblay A., Varfalvy L., dos Santos M. A. \& Matvienko, B., 2005. Carbon dioxide and methane emissions and the carbon budget of a 10-year old tropical reservoir (Petit Saut, French Guiana). Glob. Biogeochem. Cycle 19, GB4007.

Abril G., Boudou A., Cerdan P., Delmas R., Erard C., Forget P.M., Gosse P., Guerin F., Guillemet L., Pons J.M., Vaquer A.,
Vaquer Y. \& Vigouroux R., 2008. Petit Saut, bilan environnemental après 12 années de fonctionnement. Editions BUCEREP NISBN 978-2-911605-53-6.

Agostinho A.A., Miranda L.E., Bini L.M., Gomes L.C., Thomaz S.M. \& Suzuki H.I., 1999. Patterns of colonization in neotropical reservoirs, and prognoses on aging. In: Tundisi J.G. \& Straškraba M. (Eds.), Theoretical Reservoir Ecology and its Applications. International Institute if Ecology, Brazilian Academy of Sciences and Backhuys Publishers, 227-265.

Allan J.D. \& Castillo M.M., 2007. Stream Ecology - Structure and function of running waters, Springer, Dordrecht, $436 \mathrm{p}$.

Attwood S. \& Cottet M. Malacological and parasitological surveys along the $\mathrm{Xe}$ Bangfai and associated rivers: investigations into a possible 2010 outbreak of cercarial dermatitis in Khammouane Province, Lao PDR. Hydroécol. Appl. 19 (same issue).

Barros N., Cole J.J., Tranvik L.J., Prairie Y.T., Bastviken D., Huszar V.L.M., del Giorgio P. \& Roland F., 2011. Carbon emission from hydroelectric reservoirs linked to reservoir age and latitude. Nature Geosci. 4 : 593-596.

Baxter R.M., 1977. Environmental effects of dams and impoundments. Ann. Rev. Ecol. Syst. 8 : 255-283.

Beeton A.M., 1991. Limnology of the Nam Ngum Reservoir, Laos. Verh. Internat. Verein. Limnol. 24 : 1436-1444.

Beltman D.J., Clements W.H., Lipton J. \& Cacela D., 1999. Benthic invertebrate metals exposure, accumulation and community-level effects downstream from a hard- rock mine site. Environ. Toxicol. Chem. 18 : 299-307.

Bergkamp G., McCartney M., Dugan P., McNeely J. \& Acreman M., 2000. Dams, Ecosystem Functions and Environmental Restoration. World Commission on 
Dam Thematic Review Environmental Issues II.1, $187 \mathrm{p}$.

Burton E.D., Bush R.T., Sullivan L.A., Johnston S.G. \& Hocking R.K., 2008. Mobility of arsenic and selected metals during re-flooding of iron- and organicrich acid-sulfate soil. Chem. Geol. 253 : 64-73.

Cai Q.H. \& Hu Z.Y., 2006. Studies on eutrophication problem and control strategy in the Three Gorges Reservoir. Acta Hydrobiol. Sin. 30 : 7-11.

Chanudet V. \& Descloux S., 2008. Preimpoundment estimation of soil and biomass composition (excluding organic carbon) of the Nam Theun 2 reservoir. EDF report $n^{\circ}$ IH.NT-WQ.ENV.00027A, $35 \mathrm{p}$.

Chanudet V. \& Filella M., 2007. The fate of inorganic colloidal particles in Lake Brienz. Aquat. Sci. 69 : 199-211.

Chanudet V., Fabre \& V., Kaaij, T., 2012. Application of a three-dimensional hydrodynamic model to the Nam Theun 2 Reservoir (Lao PDR), J. Great Lakes Res. 38 : 260-269.

Chen H., Wu Y., Yuan X., Gao Y., Wu N., \& Zhu D., 2009. Methane emissions from newly created marshes in the drawdown area of the Three Gorges Reservoir. J. Geophys. Res. 114 : D18301.

Chen H., Yuan X., Chen Z., Wu Y., Liu X., Zhu D., Wu N., Zhu Q., Peng C. \& Li W., 2011. Methane emissions from the surface of the Three Gorges Reservoir. J. Geophys. Res. 116 : D21306.

Dai H., Zheng T. \& Liu D., 2010. Effects of Reservoir Impounding on Key Ecological Factors in the Three Gorges Region. Procedia Environ. Sci. 2 : 15-24.

Davies P.M., Bunn S.E. \& Hamilton S.K., 2008. Primary Production in Tropical Streams and Rivers. In: Dudgeon D. (Ed.), Tropical Stream Ecology. Academic Press Elsevier, London, pp. 23-42.
Descloux S., Chanudet V., Poilvé H., \& Grégoire A., 2011. Coassesment of biomass and soil organic carbon stocks in a future reservoir located in Southern Asia. Environ. Monit. Assess. 173 : 723-741.

Descloux S., Guedant P., Phommachanh D. \& Luthi R. Main features of the Nam Theun 2 hydroelectric project (Lao PDR) and the associated environmental monitoring programme. Hydroécol. Appl. 19 (same issue-a).

Descloux S., Taquet B., Wanidaporn R. \& Guedant P., 2015. Efficiency of the Nam Theun 2 downstream structures on water aeration and degassing. Hydroécol. Appl. 19 (same issue-b).

Deshmukh, C., 2013. Greenhouse gas $\left(\mathrm{CH}_{4} / \mathrm{CO}_{2} / \mathrm{N}_{2} \mathrm{O}\right)$ emissions from a newly flooded reservoir in subtropical South Asia: case of Nam Theun 2 Reservoir, Lao PDR. University Paul Sabatier (Toulouse III), Toulouse, $215 \mathrm{p}$.

dos Santos M.A., Matvienko B., Rosa L.P., Sikar E., \& dos Santos E.O., 2005. Gross greenhouse gas emissions from Brazilian hydro reservoirs. In: Tremblay A., Varfalvy L., Roehm C. \& Garneau M. (Eds.), Fluxes and Processes. Hydroelectric Reservoirs and Natural Environments. Environmental Science Series, Springer-Verlag, Berlin Heidelberg, pp. 267-291.

FLUX, 1999. Stream Load Computations (Version 5.1). Environmental Laboratory USAE Waterways Experiment Station, Vicksburg, MI. Available from: <http:// el.erdc.usace.army.mil/elmodels/ emiinfo.html> (accessed 13.11.2013)

Freund J.G. \& Petty J.T., 2007. Response of fish and macroinvertebrate bioassessment indices to water chemistry in a mined appalachian watershed. Environ. Manag. 39 : 707-720.

Friedl G. \& Wüest A., 2002. Disrupting biogeochemical cycles - Consequences of damming. Aquat. Sci. 64 : 55-65. 
Galy-Lacaux C., Delmas R., Jambert C., Dumestre J.F., Labroue L., Richard S. \& Gosse P. 1997. Gaseous emissions and oxygen consumption in hydroelectric dams: A case study in French Guiana. GlobalBiogeochem. Cycles 11 : 471-483.

Galy-Lacaux C., Delmas R., Kouadio G., Richard S. \& Gosse P., 1999. Long-term greenhouse gas emissions from hydroelectric reservoirs in tropical forest regions. Global Biogeochem. Cycles $13: 503-517$.

Gerhardt A., 1994. Short term toxicity of iron $(\mathrm{Fe})$ and lead $(\mathrm{Pb})$ to the mayfly Leptophlebia marginata L. (Insecta) in relation to freshwater acidification. Hydrobiologia 284 : 157-168.

Gong G.C., Chang J., Chiang K.P., Hsiung T.M., Hung C.C., Duan S.W. \& Codispoti L.A., 2006. Reduction of primary production and changing of nutrient ratio in the East China Sea: effect of the Three Gorges Dam? Geophys. Res. Lett. 33 : L07610.

Gosse P. \& Grégoire A., 1997. Artificial re-oxygenation of the Sinnamary downstream of Petit Saut dam (French Guiana). Hydroecol. Appl. 9 : 23-56.

Gosse P. \& Luck M., 2003. Analyse de mesures disponibles et acquises in situ en avril 2001 en vue d'une modélisation de l'oxygène dissous des rivières Nam Kathang et Sé Ban Fai (Laos). R\&D report HP-75/01/078, Electricité de France, Paris, $43 \mathrm{p}$.

Guérin F., Abril G., de Junet A. \& Bonnet M.P., 2008. Anaerobic decomposition of tropical soils and plant material: Implication for the $\mathrm{CO} 2$ and $\mathrm{CH} 4$ budget of the Petit Saut Reservoir, Appl. Geochem. 23 : 2272-2283.

Gunkel G., Lange U., Walde D. \& Rosa J.W.C., 2000. Environmental Impact of an Amazon Reservoir, Curuá-Una / Pará: Limnological Aspects. GermanBrazilian Workshop on Neotropical
Ecosystems - Achievements and Prospects of Cooperative Research Hamburg, September 3-8.

Kemenes A., Forsberg B.R. \& Melack J.M., 2007. Methane release below a Tropical Hydroelectric Dam, Geophys. Res. Lett. 34, L12809.

Kummu M. \& Varis O., 2007. Sedimentrelated impacts due to upstream reservoir trapping, the Lower Mekog River. Geomorphology 85 : 275-293.

Lampert W. \& Sommer U., 2008. Limnoecology - 2nd Edition, Oxford University Press, New York, 324 p.

Lewis W.M.Jr, 2008. Physical and Chemical Features of Tropical Flowing Waters. In: Dudgeon D. (Ed.), Tropical Stream Ecology, Academic Press Elsevier, London. 2-21.

Liu J.G., Mason P.J., Clerici N., Chen S., Davis A., Miao F., Deng H. \& Liang L., 2004. Landslide hazard assessment in the Three Gorges area of the Yangtze river using ASTER imagery: ZiguiBadong. Geomorphology 61 : 171-187.

Martinet J., Guedant P. \& Descloux S. Phytoplankton community and trophic status assessment of a newly impounded sub-tropical reservoir: case study of the Nam Theun 2 Reservoir (Lao PDR, Southeast Asia). Hydroécol. Appl. 19 (same issue).

McCartney M.P., Sullivan C. \& Acreman M.C., 2001. Ecosystem Impacts of Large Dams. Background Paper Nr. 2 Prepared for IUCN / UNEP / WCD, $82 \mathrm{p}$.

Morris G., 1998 Reservoir sedimentation handbook: Design and management of dams, reservoirs and watersheds for sustainable use, McGraw Hill Professional, $848 \mathrm{p}$.

Müller B., Berg M., Yao Z.P., Zhang X.F., Wang D. \& Pfuger A., 2008. How polluted is the Yangtze river? Water quality downstream from the Three Gorges Dam. Sci. Tot. Environ. 402 : 232-247. 
NTPC (Nam Theun 2 Power Company), 2005. Environmental Assessment and Management Plan - Nam Theun 2 Hydroelectric Project. Nam Theun 2 Power Company, Vientiane, $212 \mathrm{p}$.

Pécastaings S., Godon A., \& Roques C. Biofilm colonizing the Nam Theun 2 Power Plant penstock - mechanism and potential evolution. Hydroécol. Appl. 19 (same issue).

Peretyazhko T. \& Sposito G., 2005. Iron(III) reduction and phosphorous solubilization in humid tropical forest soils. Geochim. Cosmochim. Ac. 69 : 3643-3652.

Richard S., Arnoux A. \& Cerdan P., 1997. Evolution in physico-chemical water quality in the reservoir and downstream following the filling of Petit-Saut dam (French Guiana). Hydroecol. Appl. 9 : 57-83.

Richard S., Gosse P., Grégoire A., Delmas R., \& Galy-Lacaux C., 2005. Impact of Methane Oxidation in Tropical Reservoirs on Greenhouse Gases Fluxes and Water Quality. In: Tremblay A., Varfalvy L., Roehm C. \& Garneau M. (Eds.), Fluxes and Processes. Hydroelectric Reservoirs and Natural Environments. Environmental Science Series, Springer-Verlag, Berlin Heidelberg, 529-560.

Roland F., Vidal L.O., Pachero F.S., Barros N.O., Assireu A., Ometto J.P.H.B., Cimbleris A.C.P. \& Cole J.J., 2010. Variability of carbon dioxide flux from tropical (Cerrado) hydroelectric reservoirs. Aquat. Sci. 72 : 283-293.

Rumpel C., Alexis T.M., Chabbi A., Chaplot V., Rasse D.P., Valentin C. \& Mariotti A., 2006. Black carbon contribution to soil organic matter composition in tropical sloping land under slash and burn agriculture. Geoderma 130 : 35-46.
Serça D., Deshmukh C., Rode W. Vongkhamsao A, Pighini S., Godon A., Guédant P., Chanudet V., Descloux S. \& Guérin $F$. Methane emissions from the Nam Theun 2 Reservoir within 1804 the first 5 years after impoundment. Hydroécol. Appl. 19 (same issue).

Tang H.B., Liu G.X. \& Hu Z.Y., 2006. Preliminary research on the algal bloom of Peridiniopsis sp. in Gaolan River of the Three Gorges Reservoir. Acta Hydrobiol. Sin. 30 : 47-51.

Tullos D., 2009. Assessing the influence of environmental impact assessments on science and policy: An analysis of the Three Gorges Project. J. Env. Manage. 90 : S208-S223.

Vaquer A., Pons V. \& Lautier J., 1997. Seasonal and spatial distribution of phytoplankton in Petit-Saut Reservoir (French Guiana). Hydroécol. Appl. 9 : 169-193.

Walker W.W., 1999. Simplified procedures for eutrophication assessment and prediction: user manual, Instruction Report W- 96-2, US Army Corps of Engineers, $235 \mathrm{p}$.

Yang S.L., Zhang J. \& Xu X.J., 2007. Influence of the Three Gorges Dam on downstream delivery of sediment and its environmental implications, Yangtze River. Geophys. Res. Lett. 34 : L10401.

Yang Z., Wang H., Saito Y., Milliman, J.D., Xu, K., Qiao, S. \& Shi G., 2006. Dam impacts on the Changjiang (Yangtze) River sediment discharge to the sea: The past 55 years and after the Three Gorges Dam. Water Resour. Res. 42 : W04407.

Young E.O. \& Ross D.S., 2001. Phosphate release from seasonally flooded soils. $J$. Environ. Qual. 30 : 91-101. 